\title{
A pathway from chromosome transfer to engineering resulting in human and mouse artificial chromosomes for a variety of applications to bio-medical challenges
}

\author{
Mitsuo Oshimura • Narumi Uno • Yasuhiro Kazuki • \\ Motonobu Katoh • Toshiaki Inoue \\ Published online: 6 February 2015 \\ (C) The Author(s) 2015. This article is published with open access at Springerlink.com
}

\begin{abstract}
Microcell-mediated chromosome transfer (MMCT) is a technique to transfer a chromosome from defined donor cells into recipient cells and to manipulate chromosomes as gene delivery vectors and open a new avenue in somatic cell genetics. However, it is difficult to uncover the function of a single specific gene via the transfer of an entire chromosome or fragment, because each chromosome or fragment contains a set of numerous genes. Thus, alternative tools are human artificial chromosome (HAC) and mouse artificial chromosome (MAC) vectors, which can carry a gene or genes of interest. HACs/MACs have been generated mainly by either a "top-down approach" (engineered creation) or a "bottom-up approach" (de novo creation). HACs/MACs with one or more acceptor sites exhibit several characteristics required by an ideal gene delivery vector, including stable episomal maintenance and the capacity to carry
\end{abstract}

Responsible Editor: Natalay Kouprina and Vladimir Larionov

M. Oshimura $(\bowtie) \cdot$ N. Uno $•$ Y. Kazuki

Chromosome Engineering Research Center,

Tottori University, 86 Nishi-cho, Yonago,

Tottori 683-8503, Japan

e-mail: oshimura@med.tottori-u.ac.jp

N. Uno $\cdot$ Y. Kazuki

Department of Biomedical Science, Institute of Regenerative

Medicine and Biofunction, Graduate School of Medical

Science, Tottori University, 86 Nishi-cho, Yonago,

Tottori 683-8503, Japan

M. Katoh · T. Inoue

Division of Human Genome Science, School of Life Sciences,

Faculty of Medicine, Tottori University, 86 Nishi-cho,

Yonago, Tottori 683-8503, Japan large genomic loci plus their regulatory elements, thus allowing the physiological regulation of the introduced gene in a manner similar to that of native chromosomes. The MMCT technique is also applied for manipulating HACs and MACs in donor cells and delivering them to recipient cells. This review describes the lessons learned and prospects identified from studies on the construction of HACs and MACs, and their ability to drive exogenous gene expression in cultured cells and transgenic animals via MMCT. New avenues for a variety of applications to bio-medical challenges are also proposed.

Keywords Microcell-mediated chromosome transfer . Human artificial chromosome $\cdot$ Mouse artificial chromosome $\cdot$ Chromosome engineering $\cdot$ Humanized model mouse $\cdot$ Gene-/cell-therapy

$\begin{array}{ll}\text { Abbreviations } & \\ \text { 6-TG } & \text { 6-thioguanine } \\ \text { BAC } & \text { Bacterial artificial chromosome } \\ \text { BRCA-1 } & \begin{array}{l}\text { Breast cancer susceptibility gene I } \\ \text { Breast cancer metastasis- } \\ \text { BRMS1 }\end{array} \\ \text { suppressor 1 } \\ \text { CENP-A } & \begin{array}{l}\text { Centromere protein A } \\ \text { Chinese hamster ovary } \\ \text { CHO }\end{array} \\ \text { CRISPR } & \begin{array}{l}\text { Clustered regulatory interspaced } \\ \text { short palindromic repeat }\end{array} \\ \text { CSN2 } & \begin{array}{l}\text { Beta-casein } \\ \text { Cytochrome P450, family 3, }\end{array} \\ \text { CYP3A } & \text { subfamily A } \\ \text { CYP3A-HAC } & \text { CYP3A cluster-containing HAC }\end{array}$


DMD

DS

DYS-HAC

EGFP

ES

FVIII

GALC

GATA1s

$\mathrm{GCH} 1$

$\mathrm{H} / \mathrm{F}$ protein

HAC

HAT

hCFs

hiMSC

HLA

HPRT

iHAC

iPS

LIT1(KCNQ1OT1)

MAC

MEFs

mGS cells

MI-HAC

MMCT

MUC4

MV

NBS1

OPN

PAC

PDLs

PEG

PITX1

SATAC

$\mathrm{scFv}$

SIM

ssODN

TALE
Duchenne musclular dystrophy

Down syndrome

Genomic dystrophin locus-

containing HAC

Enhanced green fluorescent

protein

Embryonic stem

Human factor VIII

Galactosylceramidase

GATA-binding protein 1 shorter

isoform

GTP cyclohydrolase 1

Hemagglutinin/fusion protein

Human artificial chromosome

Hypoxanthine-aminopterin-

thymidine

Human chromosome fragments

Human immortalized

mesenchymal stem cell

Human Leukocyte Antigen

Hypoxanthine phosphoribosyl

transferase

iPS cell-inducible HAC

Induced pluripotent stem

Imprinted antisense RNA in the

human KvLQT1

Mouse artificial chromosome

Mouse embryonic fibroblasts

Multipotent germline stem cells

Multi-integrase HAC

Microcell-mediated chromosome

transfer

Mucin 4

Measles virus

Nijmegen breakage syndrome 1

Osteopontin

P1-derived artificial chromosome

Population doubling levels

Polyethylene glycol

Paired-like homeodomain 1

Satellite-DNA-based artificial

chromosome

Single-chain variable fragment

Simultaneous or sequential

integration of multiple gene-

loading vectors

Single-strand donor

oligonucleotides

Transactivator like effector
TALENs

TAM

TAR

Tc mouse

tet-O

TfR

Ts 21

VHL

YAC

ZFP

ZFNs

\section{Microcell-mediated chromosome transfer}

\section{Dawn of MMCT}

Fournier and Ruddle performed for the first time microcell-mediated chromosome transfer (MMCT) (Fournier and Ruddle 1977). Several research groups have published seminal studies on the construction of mouse A9- or Chinese hamster ovary (CHO)-microcell hybrid libraries containing a single human chromosome tagged with a selectable genetic marker for MMCT (Fig. 1). A human chromosome tagged with a dominant selectable gene in the microcell-hybrids can be transferred to other cells. Therefore, the microcell hybrids provide valuable resources not only for mapping and cloning human genes but also for functional studies of specific genes and the production of animal models (Tomizuka et al. 1997; Shinohara et al. 2001; Meaburn et al. 2005; Devoy et al. 2011).

Briefly, donor cells (normally mouse A9 fibroblast cells and $\mathrm{CHO}$ ) cells are induced to multinucleate their chromosomes (referred to as micronucleus formation). Micronuclei are then forced through the cell membrane to create microcells by centrifugation in the presence of cytochalasin B which disrupts the cytoskeleton (Ege and Ringertz 1974). These microcells can be fused to a recipient cell line in the presence of polyethylene glycol (PEG) which acts as a dehydrating agent and fuses plasma membranes. Thus, MMCT consists of two technologies, cell fusion and multinucleation. Since the basic procedure was established in 1970s, the essential part of the procedure has not changed. 
Human fibroblast

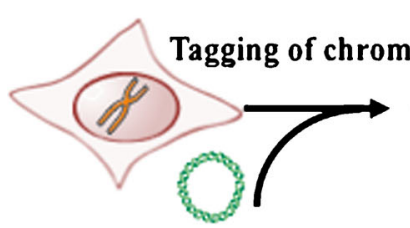

Positive selectable marker (pSTneo)

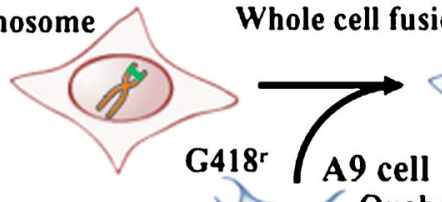

Ouabain

A9 hybrid

Micronuclei formation

Micronuclei formation ability
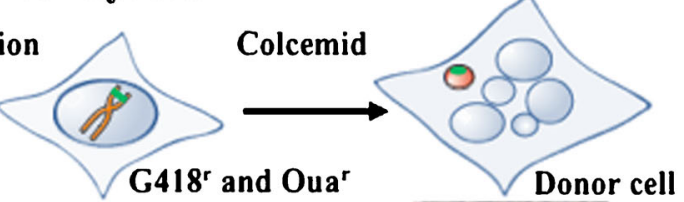

Micronuclei formation ability

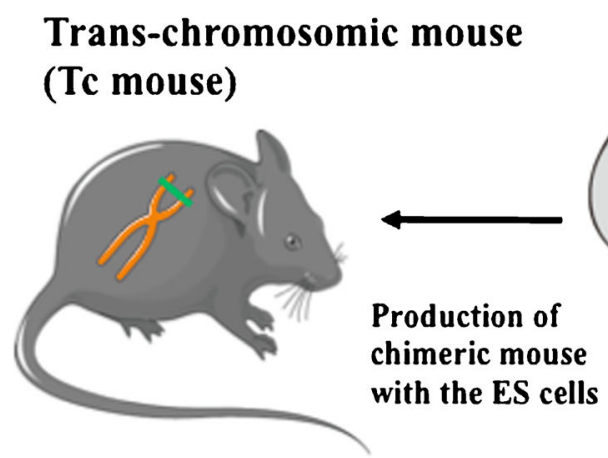

Fig. 1 Microcell-mediated chromosome transfer (MMCT) for generation of monochromosomal hybrid cells and transchromosomic mice. Construction of mouse A9 hybrid cells carrying a single human chromosome by MMCT: the first step involves marking the human chromosome in the fibroblasts with a selection marker and fusing the fibroblasts with mouse A9 cells. The second step is the introduction of the marked human chromosome from the donor hybrid to the

The formation of multi-micronuclei is thought to be related to the condensed, scattered chromosomes that result from mitotic arrest caused by microtubule inhibitors. These scattered chromosomes reportedly serve as sites for the reassembly of nuclear membranes, forming micronuclei in which chromosomes decondense before returning to a pseudo-G1 phase (Crenshaw et al. 1981).

Cancerous or spontaneous micronuclei, which serve as an indicator of chromosomal instability, are small extra nuclei apart from primary nuclei in the same cell and are thought to be formed in an essentially similar manner to multi-micronuclei formed in $\mathrm{A} 9$ and $\mathrm{CHO}$ cells. However, multi-micronuclei and cancerous micronuclei differ in their number in a cell. The mechanism to create two different types of micronuclei in a cell-type-dependent manner remains unclear. Our observation suggests that $\mathrm{A} 9$ and $\mathrm{CHO}$ cells undergo repetitive hyperploidization in the presence of colcemid, and recurrent micronucleation occurs during transition from recipient A9 cells. The procedure can be divided into several parts, as follows: micronucleation of the donor hybrids by colcemid treatment, enucleation in the presence of cytochalasin $\mathrm{B}$, purification of the microcells, fusion with the recipient A9 cells, drug selection of the microcell hybrids, identification of the transferred human chromosome by fluorescence in situ hybridization, and DNA analyses. This figure was produced using Servier Medical Art (http://www.servier.com)

metaphase to pseudo-G1 to form smaller and more numerous micronuclei (Nakayama et al. 2015), whereas cancerous micronuclei formation is often associated with cell death. Thus, it appears that A9 and $\mathrm{CHO}$ cells have a system to escape from cell death provoked by mitotic error.

A variety of applications of MMCT technique

MMCT technique has been applied to various types of studies since the 1970s. First, MMCT has contributed to mapping of genes whose defects resulted in clear cellular phenotype as shown by functional complementation studies (Meaburn et al. 2005; Doherty and Fisher 2003). This type of application includes gene mapping/isolation for tumor suppression (Oshimura and Barrett 1997), DNA repair (Matsuura et al. 1997, 1998; Horibata et al. 2004), metastasis, telomerase regulation, and genomic instability (Matsuura et al. 2006), mitochondrial disorders (Seyda et al. 2001), and 
lysosomal storage diseases (Kurimasa et al. 1993). Second, it has been applied to recapture and analysis of specific chromosome status in situations such as aneuploidy and Down syndrome (DS) and in epigenetics (Devoy et al. 2011; O'Doherty et al. 2005; Kazuki et al. 2014). Third, it has been applied to chromosome function study such as kinetochore assembly, telomere function, and high-order chromosome architecture (Wakai et al. 2014; Kouprina et al. 2014). Fourth - a new type of application of MMCT of mammalian artificial chromosome vectors - has recently been reported such as humanized animal transgenesis and cell and gene therapy, multi-reporter assay system, and high-yield protein production (Kazuki and Oshimura 2011; Oshimura et al. 2013). This fourth application will be further discussed later, while here we will now present representative applications of MMCT of the other three types.

\section{Identification of tumor, metastasis, and telomerase suppressor genes}

The studies using MMCT technique applied to human cancer cell lines have shown that tumor suppressor genes locate on Chr. 1, 3-13, 17-19, 22, and X (Oshimura and Barrett 1997; Doherty and Fisher 2003). The transfer of these chromosomes leads to growth suppression in vitro or decreased tumorigenicity in vivo. Since it is difficult to obtain and analyze the cells with growth suppression, revertants with spontaneous deletion on the transferred chromosome have often been used to identify the responsible region(s). Although the responsible genes on each chromosome have not yet been identified in many cases, recent advances in DNA sequencing technology would help the identification. Also, a combination of RNAi/genomeediting techniques (Joung and Sander 2013; Sander and Joung 2014) for knockdown/knockout of candidate gene(s) on the defined chromosome with MMCT technique would be useful. For example, the genes or regions on the transferred chromosome, whose knockdown or knockout in chromosome-transferred cells reverse the phenotypes of growth and tumorigenicity can be candidates for tumor suppressor genes/regions.

As well, metastasis-suppressor genes have been reported, which locate on Chr.1, 2, 6-8, 10-13, 16,17, and 20 (Doherty and Fisher 2003; Cheung et al. 2009; Ichikawa et al. 1994). Breast cancer metastasis-suppressor 1 (BRMS1), encoded at chromosome 11q13, has been identified as a breast carcinoma metastasis-suppressor gene (Seraj et al. 2000).

Telomerase, a ribonucleoprotein enzyme that maintains telomere length, is crucial for cellular immortalization and cancer progression. The loss of the activity sometimes leads to growth suppression in cancer cell lines. By essentially the same approach as identification of tumor suppressor regions, the identification of telomerase suppressor genes has been performed (Oshimura and Barrett 1997; Tanaka et al. 1998; Nishimoto et al. 2001; Kugoh et al. 2003; Abe et al. 2010). To date, telomerase suppressor genes have been found on almost all human chromosomes. Notably among the studies, Kugoh et al. has successfully identified PITX1-a member of the bicoid-related homeobox transcription factors - as a telomerase suppressor gene located on human chromosome 5 (Qi et al. 2011). The authors performed complementary DNA (cDNA) microarray analysis using parental telomerase-positive melanoma cells, telomerase-negative cell hybrids with a transferred human chromosome 5, and its revertant clones with reactivated telomerase. Thus, this study supports the notion that a combination of the latest biotechnology with the MMCT technique can lead to functional identification of genes as mentioned above.

\section{Aneuploidy}

A change in chromosome number, referred to as aneuploidy, is commonly observed in tumors. The observation that chromosomal aneuploidies arise in a tumor stage-specific manner suggests that they play a fundamental role in tumorigenesis. However, the relationship between aneuploidy and cancer remains unclear. For example, it is not known whether chromosomal aneuploidy affects chromosome-specific gene expression and whether it also affects gene expression on other chromosomes. MMCT methodology allows one to model specific chromosomal aneuploidies in cancer cells.

Three different chromosomes have been introduced into karyotypically diploid, colorectal cancer cells, and into immortalized normal breast epithelial cells (Upender et al. 2004). Their study showed that regardless of chromosome or cell type, chromosomal trisomies lead to a significant increase in the average transcriptional activity of the trisomic chromosome. In addition, this increase affects the expression of numerous genes on other chromosomes as well, suggesting 
that a complex pattern of transcriptional dysregulation exists in aneuploidy. Also, our group had established aneuploidy in mouse embryonic stem (ES) cells by transferring various human chromosomes or spontenous mouse chromosmal abnormalities and revealed a common cluster of down-regulated genes independent of the transferred human chromosome, of which eight known genes are related to cell proliferation, neurite outgrowth, and differentiation (Kai et al. 2009). This suggests that autosomal imbalance may commonly lead to dysregulation of apoptosis.

Recently, in vitro chromosome abnormality syndrome models with a genetic alteration were generated by combining chromosome transfer and genome-editing technologies (Kazuki et al. 2014). To gain insights into the underlying mechanisms of the progression to transient abnormal myelopoiesis (TAM) in DS patients, human pluripotent stem cells harboring Trisomy 21 (Ts21) and/or GATA-binding protein 1 shorter isoform (GATA1s) were generated via MMCT and zinc-finger nucleases (ZFN). The DS model cells generated by these two technologies are useful in assessing how GATA1s mutation is involved in the onset of TAM in patients with DS. Transfer of the modified chromosome or human artificial chromosome (HAC)/mouse artificial chromosome (MAC) with desired gene(s) via MMCT and disruption of a target gene(s) via genome editing will enable the identification of genes responsible for disease phenotypes.

\section{Epigenetics}

Epigenetics refers to heritable changes in gene expression that do not involve changes in DNA sequence. DNA methylation, histone modification, chromatin remodeling, transcription factors, and non-coding RNAs are currently considered to regulate epigenetic change (Bird 2007).

Genomic imprinting is the phenomenon of parent-oforigin gene expression. Appropriate expression of imprinted genes is important for normal development; their dysregulation is associated with numerous diseases such as Beckwith-Wiedemann syndrome, Angelman syndrome, and cancer. Our group has established a series of human monochromosomal hybrids housed in mouse A9 cells by using MMCT (Kugoh et al. 1999). Since the parental origin of the transferred chromosome is known, this library contributed in identifying a number of imprinted genes including LIT1, a long non- coding RNA gene involved in Beckwith-Wiedemann syndrome (Mitsuya et al. 1999; Meguro et al. 2001).

Chromosome 11 carrying LIT1 locus was transferred to homologous recombination-proficient chicken DT40 cells for targeted modification of the LIT1 genome, and then further transferred to $\mathrm{CHO}$ cells for the expression analysis of imprinted gene on the 11 p15.5 region. This study successfully identified a putative imprinting control element playing an essential role in Beckwith-Wiedemann syndrome (Horike et al. 2000). The latest genome-editing technology described in the following section would allow direct genome modification in monochromosomal hybrids including A9 and CHO cells in much less time and with narrowing down of the region of interest without using DT40 cells. Also, monochromosomal hybrids still provide a good model to study chromatin organization on a centromeric region (Fukagawa et al. 2004).

\section{Towards a high efficiency of MMCT}

Since the dawn of MMCT trials, established cell lines such as mouse ES cells have been preferably used as recipient cells. Efficiency of MMCT has been described by the ratio of drug-resistant colony number to recipient cells. Depending on the type of recipient cells, the efficiency is generally $10^{-5} \sim 10^{-6}$ when using PEG for fusion of microcells and recipient cells. With the advent of stem cell studies, the target of MMCT has been extended to primary cells with finite life-span, somatic stem cells, and induced pluripotent stem (iPS) cells. Improvement of the efficiency has emerged as an issue to be resolved.

As mentioned in the previous section, MMCT comprises multiple steps, viz., (1) induction of micronuclei in donor cells, (2) isolation of microcells from micronucleated donor cells, (3) fusion of microcells with recipient cells, (4) integration of the transferred chromosome into host cell nucleus, and (5) selection of microcell hybrid cells by drug selection. Eventual efficiency is determined by the summation of contribution from each step. Of these steps, we will discuss microcell fusion and provide a perspective for effective isolation of microcells.

\section{PEG fusion}

PEG is most commonly used as a fusogen in microcell fusion and whole cell fusion by which monoclonal 
antibody-producing hybridomas have been routinely made (Yang and Shen 2006). Depending on the type of recipient cells, the microcell fusion efficiency where PEG is used is usually $10^{-5} \sim 10^{-6}$. The mixture of microcells and recipient cells is transiently exposed to PEG, followed by dilution and removal by washing. Theoretically, one-to-one fusion between a pair of microcell and recipient cell produces a seed of microcell hybrid. But the PEG treatment is injurious to cell membrane, and overexposure to PEG reduces the viability of hybrid cells (Golestani et al. 2007). Furthermore, exposure of cells to PEG is difficult to precisely control in practice. As a common feature of established cell lines is infinite proliferation capacity, drug-resistant hybrids could easily arise, regardless of damage caused by PEG exposure. MMCT by PEG has been attempted with primary human fibroblasts or bone marrow-derived mesenchymal stem cells, but hybrids had been scarcely obtained (unpublished data). Substitution of fusogen from highly toxic PEG to less-toxic reagents might aid in generating microcell hybrids from primary cells.

\section{Virus fusion}

The first microcell cell fusion experiment was carried out by using Sendai virus as fusogen (Fournier and Ruddle 1977). But from difficulties in preparation of virus particle, virus fusion had been replaced with more convenient PEG fusion. Envelope-typed virus, which is coated by lipid bilayer membrane inherited from the infected host cells, makes use of an envelope protein(s) for the infection into next host cells. Sendai virus represents two distinct glycoproteins on the envelope for infection (Okada 1993). Hemagglutinin neuraminidase protein binds to sialic acid receptors on the host cell surface and degrades the receptor by sialidase activity. Fusion protein then associates with lipid molecules, such as cholesterol, embedded in the lipid bilayer membrane, and induces cell fusion. Utilization of inactivated virus particle for whole cell fusion had been reported since 2004 (Hiraoka et al. 2004), due to appearance of commercially available reagent. Application of the inactivated virus particle has also been reported for microcell fusion (Yamaguchi et al. 2006; Nawata et al. 2011; Lee et al. 2013). However, efficiency of MMCT was comparable but not superior to when PEG was used, even though immortalized cells were used as recipients. Unwanted secondary fusion between microcell hybrids and adjacent cells might hamper the survival of microcell hybrids.
Fusion by viral fusogenic proteins presented on the microcell surface

During the course of virus particle formation in the infected cells, viral fusogenic proteins are synthesized de novo, transported to the cell periphery, and presented on the cell surface, followed by extrusioin of cell membrane as virus envelope (Navaratnarajah et al. 2009). This well-controlled budding mechanism of envelope virus prompted us to make "a fusogenic microcell" which carries a chromosome to be transmitted and is coated with fusogenic envelope proteins. We chose fusogenic envelope proteins from measles virus (MV) with which accumulating data has been reported. MV has two envelope glycoproteins, hemagglutinin $(\mathrm{H})$ and fusion (F) proteins, for infection into host cells. Virus particle specifically attaches to the surface of host cells by the interaction between $\mathrm{H}$ protein and its receptors on the host cell surface. Binding of the $\mathrm{H}$ protein to a receptor triggers the fusion of virus envelope with the host cell membrane by the mediation of $\mathrm{F}$ protein. To make "fusogenic microcells," expression plasmids encoding $\mathrm{H}$ and $\mathrm{F}$ protein were transfected into $\mathrm{CHO}$ cells carrying a HAC vector. Microcells isolated from the $\mathrm{CHO}$ donor cells showed fusion ability to recipient human cells that express a receptor protein CD46, leading to successful transfer of the HAC (Katoh et al. 2010). It was noted that the MMCT efficiency depended on the expression level of CD46 in recipient cells. CD46 belongs to the family of complement activation regulators that prevent self-cell destruction (Dhiman et al. 2004). Overexpression of CD46 is frequently observed in cancer cells to overcome lysis by complement (Anderson et al. 2004). Indeed, in case of fibrosarcoma cell line HT1080 which has high surface density of CD46, the MMCT efficiency was 2 orders in magnitude higher than that of PEG fusion. However, in case of primary fibroblasts that have low surface density of CD46, the efficiency was comparable with that of PEG fusion. An issue with this method is the narrow range of recipient cells that can be used to obtain high efficiency fusion. The preceding studies that describe the usage of MV for oncolysis by infection, have proposed retargeting of MV by engineering the $\mathrm{H}$ protein, i.e., addition of single-chain antibody fragment against surface receptors other than CD46 (Nakamura et al. 2004; Nakamura et al. 2005). Addition of single-chain variable fragment $(\mathrm{scFv})$ against transferrin receptor (TfR) improved fusion efficiency to primary fibroblasts 
(unpublished data). Although high affinity $\mathrm{scFv}_{\mathrm{v}}$ to desired surface receptor is not always available with ease, retargeting of MV may be an alternative for PEG-sensitive cells.

Isolation and storage of microcells

Microcell population prepared from donor cells is composed of a variety of subpopulations carrying (1) a chromosome (HAC or MAC) to be transferred, (2) chromosomes derived from host cells, or (3) no choromosomal DNA. Only the first subpopulation contributes to intended MMCT, but it is minor among all the components. In the current protocol, total mixed population is used for fusion with recipient cells, and intended microcell hybrids are chosen by selection culture with antibiotics by utilizing the drug-resistant gene tagged onto the HAC/MAC. Preferential fractionation of required microcell subpopulation from the total mixture, if possible, might aid in achieving more intentional fusion reaction and in needing a smaller number of recipient cells.

The conventional MMCT method is usually performed immediately after the purification of microcells. The timing of the isolation of microcells and the preparation of recipient cells is very important. A cryopreservation method to store microcells at $-80{ }^{\circ} \mathrm{C}$ was performed and compared the efficiency of MMCT with conventionally (immediately) method. There was no significant difference between the two methods regarding chromosome transfer efficiency. Thus, cryopreservation of ready-to-use microcells is useful for the MMCT (Uno et al. 2013).

In order to isolate a single microcell-containing HAC/MAC, potential clues might be emerged from recent advancement in genome engineering technology, including zinc finger protein (ZFP), transactivator-like effector (TALE), and clustered regulatory interspaced short palindromic repeat (CRISPR)/Cas9 system (Urnov et al. 2010; Joung and Sander 2013; Sander and Joung 2014). Dynamics of a specific chromosome locus in living cells becomes detectable by tagging with DNA/RNA-binding protein fused with fluorescent proteins. Both long repetitive sequences such as telomeres or satellite centromeric DNA and short repetitive sequences such as within the intron of endogenous MUC4 gene were visualized by the fusion of a fluorescent protein with TALE or CRISPR/Cas9 (Miyanari et al. 2013; Ma et al. 2013; Chen et al. 2013).
In donor cells, centromere satellite of $\mathrm{HAC} / \mathrm{MAC}$ is distinct from that of host chromosome; HAC/MACspecific tagging at centromere may therefore be an attractive option. Microcells carrying HAC/MAC might be fractionated by FACS technology and efficiently transferred to desired cells or to a small number of cells, if they were specifically tagged with fluorescent fusion proteins utilizing genome engineering technology.

Various types of HACs and MACs as episomal vectors

\section{Transition of the cargo in MMCT from whole chromosome to HAC/MAC}

In transferring a single chromosome or fragment, it is difficult to uncover the function of a specific gene because each chromosome or fragment contains a set of numerous genes. Thus, alternative tools are HAC and MAC vectors, which can carry a gene or genes of interest.

Most, but not all, conventional vectors present problems associated with their limited cloning capacity, lack of copy number control, and insertional mutagenesis caused by integration into host chromosomes (Kouprina et al. 2014; Kazuki and Oshimura 2011). HACs and MACs are exogenous mini-chromosomes artificially created by either a top-down approach (engineered creation) or a bottom-up approach (de novo creation). In chromosomes engineered by a top-down approach, mini-chromosomes are derived from endogenous chromosomes following their natural fragmentation or telomere-directed chromosome breakage (Heller et al. 1996; Kazuki et al. 2011; Takiguchi et al. 2012). The HAC/MAC can then be transferred into other cell lines by MMCT. In de novo artificial chromosomes engineered by a bottom-up approach, exogenous chromosomes can be circular or linear, created de novo from cloned chromosomal components that possess a functional centromere, and can autonomously replicate and segregate. A summary of various chromosomal vectors and their acceptor site(s) and characteristics is provided in Table 1 . The recent demonstration that chromosomal vectors can incorporate a gene or genes has increased their utility and potential application (Kouprina et al. 2014; Kazuki and Oshimura 2011; Oshimura et al. 2013) (Fig. 2). 
Table 1 A list of HACs/MACs with various acceptor site(s) for gene delivery (modified from Kazuki et al. 2011)

\begin{tabular}{|c|c|c|c|c|}
\hline Name of HACs & Construction method & Origin of centromere & $\begin{array}{l}\text { Insertion sites (copy number } \\
\text { of the insertion site) }\end{array}$ & Reference \\
\hline Tet-O HAC & De novo & $\begin{array}{l}\text { Human chromosome } 17 \\
\text { alphoid }\end{array}$ & $\begin{array}{c}\text { loxP (single/multiple), SIM } \\
\text { system (loxP/attB/attP) }\end{array}$ & Iida et al. (2010) \\
\hline $25-4$ vector & De novo & $\begin{array}{l}\text { Human chromosome } 21 \\
\text { alphoid }\end{array}$ & Mutant lox 71 (multiple) & Ikeno et al. (2009) \\
\hline $21 \Delta \mathrm{pqHAC}, 21 \Delta \mathrm{qHAC}$ & Engineered & Human chromosome 21 & loxP (single) & Katoh et al. (2004) \\
\hline $\begin{array}{l}\text { 21HAC } 1,21 \mathrm{HAC} 2,21 \mathrm{HAC} 3, \\
\text { 21HAC4 }\end{array}$ & Engineered & Human chromosome 21 & loxP (single) & Kazuki et al. (2010) \\
\hline MI-HAC (21HAC1-modified HAC) & Engineered & Human chromosome 21 & $\begin{array}{l}\text { FRT, } \varphi \text { C31 attP, R4attP, } \\
\text { TP901attP, Bxb1attP (single) }\end{array}$ & Yamaguchi et al. (2011) \\
\hline Human mini-chromosome & Engineered & Human chromosome Y & attB (single) & Dafhnis-Calas et al. (2005) \\
\hline $\mathrm{CV}(\mathrm{HCV} / \mathrm{SAC})$ & $\begin{array}{l}\text { Patient-derived accessory } \\
\text { chromosome }\end{array}$ & Human chromosome 20 & loxP (unknown copy number) & Voet et al. (2003) \\
\hline $\mathrm{MC}$ & $\begin{array}{l}\text { Patient-derived accessory } \\
\text { chromosome }\end{array}$ & Human chromosome 9 & $\operatorname{lox} \mathrm{P}(5$ copies $)$ & Moralli et al. (2001) \\
\hline SC20-HAC & Chromosome fragment & Human chromosome 14 & loxP (single) & Kuroiwa et al. (2000) \\
\hline $\begin{array}{l}14 \mathrm{~A} \Delta \mathrm{qHAC}, 14 \mathrm{~N} \Delta \mathrm{qHAC}, \\
14 \mathrm{gN} \Delta \mathrm{qHAC}\end{array}$ & Engineered & Human chromosome 14 & loxP (single) & Kakeda et al. (2011) \\
\hline SATAC & $\begin{array}{l}\text { De novo (murine } \\
\text { satellite DNA based) }\end{array}$ & Murine chromosome 7 & loxP (multiple) & Stewart et al. (2002) \\
\hline Platform ACE (SATAC) & $\begin{array}{l}\text { De novo (murine } \\
\text { satellite DNA based) }\end{array}$ & Murine chromosome & attP (multiple) & Lindenbaum et al. (2004) \\
\hline $\mathrm{MAC} 1, \mathrm{MAC} 2$ & Engineered & Murine chromosome 11 & loxP (single) & Takiguchi et al. (2012) \\
\hline MI-MAC (MAC2-modified MAC) & Engineered & Murine chromosome 11 & $\begin{array}{l}\text { FRT, } \varphi \text { C31 attP, R4attP, } \\
\text { TP901attP, Bxb1attP (single) }\end{array}$ & Takiguchi et al. (2012) \\
\hline
\end{tabular}

\section{$H A C s$}

HACs display a number of advantages over conventional vectors, e.g., they do not integrate into the host genome and the size of gene(s), which they can carry is not limited (Fig. 2). The de novo assembly of HACs using the bottom-up approach has been developed in human fibrosarcoma HT1080 cells (Harrington et al. 1997; Ikeno et al. 1998; Kouprina et al. 2003; Basu et al. 2005b). In most cases, de novo generated HACs range from 1 to $10 \mathrm{Mb}$ in size. An issue of de novo HAC was the restriction of HAC formation to a single cell type HT1080. Recently, Masumoto and colleagues discovered that in HT1080 cells, the level of H3K9me3 on alphoid DNA is substantially lower than in other human cell lines (Ohzeki et al. 2012). In other types of human cells, heterochromatin enriched with $\mathrm{H} 3 \mathrm{~K} 9 \mathrm{me} 3$ is assembled quickly on the transfected alphoid DNA array, thus preventing CENP-A retention and HAC formation. It has been shown that tethering of histone acetyltransferases to the input alphoid DNA arrays breaks this celltype-specific barrier for de novo CENP-A assembly and allows assembly of other kinetochore proteins, thereby leading to HAC formation in a wide range of cell types. Other systems for the construction of HACs have been developed to rapidly create bacterial artificial chromosome (BAC)-based HACs using the red-recombination system from bacteriophage $\lambda$ (Kotzamanis et al. 2005) or using a modified bacterial Tn5 transposon (Basu et al. 2005b). Utilization of invasive Escherichia coli systems may facilitate de novo HAC formation (Narayanan and Warburton 2003). A technique based on the HSV1 amplicon greatly improved de novo HAC formation protocols (i.e., much higher efficiency and applicability to many different cell lines other than HT1080) (Moralli et al. 2006). HACs have been generated in immortalized cell lines such as HT1080 but never in stem cells. Recently, de novo HACs were also generated in human ES cell lines (Mandegar et al. 2011). Thus, this technology is potentially suitable for a wide variety of applications.

Another HAC with a conditional centromere that includes the tetracycline operator (tet-O) sequence embedded in the alphoid DNA array has been generated (Nakano et al. 2008). This conditional centromere can be inactivated by expression of tet-repressor fusion 


\section{Construction of 21HAC The lox $P$ targeting and telomere truncation on Chr.X}

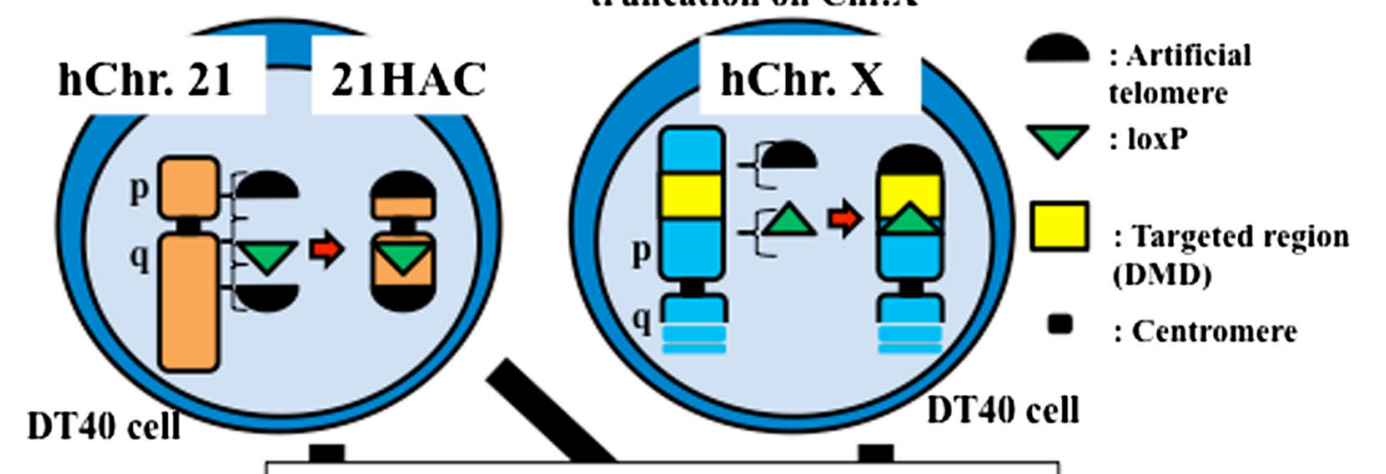

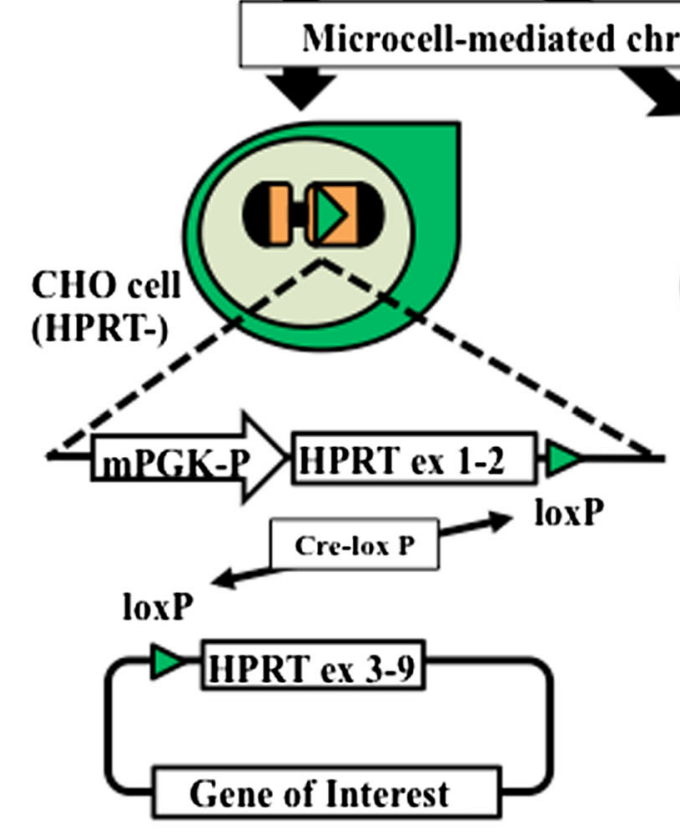

Loading of circular DNA by insertion

Fig. 2 Two types of gene loading to HAC. (a) Construction of a human artificial chromosome (HAC) vector from human chromosome 21 using the top-down approach. The 21HAC is equipped with a $\operatorname{lox} P$ site for loading the gene of interest. A site-specific recombination event mediated by Cre recombinase is selected by reconstruction of the functional HPRT gene, which confers

proteins, resulting in loss of the tet-O HAC. Since the desired gene cannot be inserted into the tet-O HAC without an acceptor site such as loxP or FRT, the tet-O $\mathrm{HAC}$ vector was adapted for gene delivery and gene expression in human cells (Iida et al. 2010). Thus, a loxP cassette was inserted into the tet-O HAC by homologous recombination in chicken DT40 cells. The tet-O HAC with the loxP cassette was then transferred into $\mathrm{CHO}$ cells. It has been shown that the enhanced green

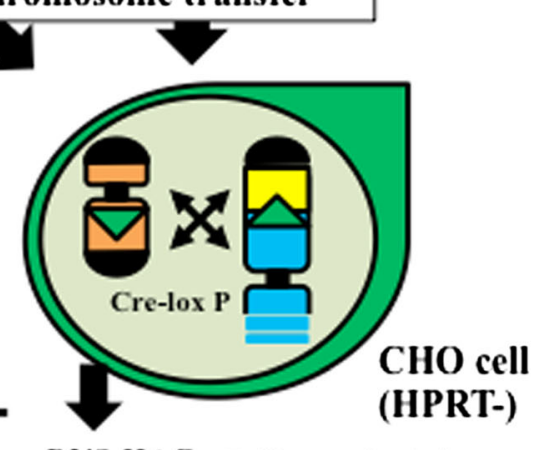

DYS-HAC $=$ By-product chromosome

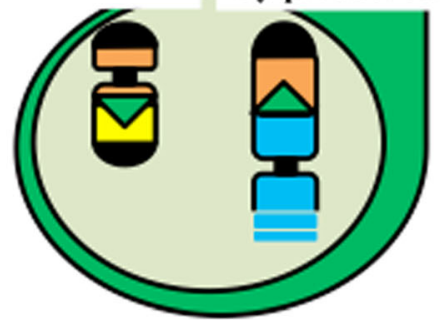

Loading of linear DNA by reciprocal chromosomal translocation

hypoxanthine-aminopterin-thymidine (HAT) resistance. (b) The gene of interest, isolated in a circular vector, is introduced into the HAC by site-specific insertion. (c) A megabase-size gene locus, which is above the capacity of circular cloning vectors, is introduced into the HAC by site-specific reciprocal chromosome translocation

fluorescent protein (EGFP) transgene was efficiently and accurately incorporated into the tet-O HAC vector. The EGFP transgene was stably expressed in human cells after transfer via MMCT, and the transgenes inserted into the tet-O HAC were subsequently eliminated from cells by loss of the HAC due to centromere inactivation. The tet-O HAC vector has significant advantages over other expression/cloning systems because it provides a mechanism to compare the phenotype of a 
mammalian cell with or without a functional copy of any cloned gene of interest.

Conversely, HACs engineered via the top-down approach can also be constructed by telomereassociated chromosome fragmentation techniques in the homologous recombination-proficient chicken cell line, DT40 (Buerstedde and Takeda 1991). Such an approach can generate mitotically stable, linear minichromosomes. Initially, mini-chromosomes ranging in size from 0.5 to $10 \mathrm{Mb}$ have been produced from both the human X (Farr et al. 1992) and Y chromosomes (Brown et al. 1994). These mini-chromosomes retain a normal centromere and are mitotically stable in human cells with only minor rearrangements. A novel 21HAC vector in which known endogenous genes were absent was developed using the top-down approach from human chromosome 21 (Kazuki et al. 2011). This $21 \mathrm{HAC}$ was physically characterized using a transformation-associated recombination (TAR) cloning strategy followed by sequencing of TAR-BAC clones, confirming that no known endogenous genes remained in the 21HAC. Thus, the 21HAC vector contains four useful features: (1) it has a well-defined genetic architecture; (2) it is present episomally, independent of the host chromosomes; (3) it is mitotically stable in human cells in vitro; and (4) any desired gene can be cloned into the 21HAC using the Cre/loxP system in CHO cells or by a homologous recombination system in DT40 cells (Kazuki et al. 2011; Kouprina et al. 2014; Oshimura et al. 2013). Using the Cre/loxP system, gene cloning can be performed by insertion- or translocation-type cloning (Fig. 2). Circular vectors such as plasmids, P1derived artificial chromsome (PAC) s and BACs containing desired genes can be inserted into the HAC vector by insertion-type cloning. Megabase-sized genes, which cannot be cloned into the circular vectors, can be cloned into the HAC vector using translocation-type cloning (Hoshiya et al. 2009). Furthermore, using the homologous recombination system, two different vectors, each containing a desired gene, were inserted sequentially into $21 \mathrm{HAC} 1$ by homologous recombination in DT40 cells. Two or more vectors containing desired genes can be inserted sequentially into the HAC. The genome-editing technology will also enable us to perform this recombination process easily without using DT40 cells. Therefore, any combination of genes, including full-length genomic DNA, can in theory be cloned into the HAC by a combination of these cloning systems and transferred into a desired recipient cell type using the HAC. Thus, these novel $21 \mathrm{HAC}$ vectors may be useful for gene and cell therapies as well as for animal transgenesis. The novel HAC vector may be generated using genome-editing technologies in human primary or iPS cells via top town approach for safe gene and cell therapy, without using intermediate host cells such as DT40 cells although the technologies for transfer of the HAC from normal human cells to desired patient cells without using A9 or CHO cells need to be developed.

\section{MACs}

Recently, a MAC vector was constructed from a natural mouse chromosome by means of the top-down approach (Takiguchi et al. 2012). In order to use the MAC as a functional gene vector, the faithful segregation of the MAC vector was investigated after its transfer to mouse embryonic stem (ES) cells and in transchromosomic (Tc) mice. Although human chromosome fragments (hCFs) and HACs with a large genomic region of interest could be autonomously maintained in Tc mice, their retention rate was variable in mouse ES cell lines and the tissues of Tc mice, possibly owing to their gradual loss during cell growth. On the other hand, MAC vectors are stably maintained in mouse ES cells and various tissues in Tc mice as well as in human cell lines (Takiguchi et al. 2012; Kazuki et al. 2013a). The MACs have acceptor sites into which a desired gene or genes can be inserted, similar to the HACs described above. Tc mice containing the MAC vector may be valuable tools for functional genome analyses in in vitro and in vivo models.

Furthermore, a satellite-DNA-based artificial chromosome (SATAC) was created via amplicon-dependent de novo chromosome formation induced by the integration of exogenous DNA sequences into centromeric DNA regions near the pericentric heterochromatic or acrocentric chromosome (Lindenbaum et al. 2004).

A mini-chromosome, ST1, was developed from the human Y chromosome, which is linear, has a molecular weight of approximately $4.5 \mathrm{Mb}$, and contains incidentally acquired mouse major and minor satellites as well as human DNA, including tandemly repeated alphoid DNA sequences (Shen et al. 1997). At the present time, the most suitable chromosome vectors reported in the literature remains uncertain, because comparative studies in the 
same condition (cell lines, mouse lines, culture method, etc.) has not been reported.

\section{Technologies for multiple acceptor sites on chromosome vectors}

One of the major problems with gene transfer into mammalian cells by standard methods of plasmid transfection or virus vector infection is poorly reproducible expression level of the transferred gene between different transformants because of chromosome position effect and copy-number variation. Targeted integration of DNA into the acceptor site on the chromosomal vectors promises a simple solution to the problems from random integration of the transferred gene.

Chromosomal vector is maintained in mammalian host cells. Prototype chromosomal vector utilizes the Cre/loxP system for site-specific insertion of circular donor vector into the cloning site on the chromosomal vector (Fig. 2). Donor vector carries a gene of interest, loxP cassette, and a part of a drug-resistant marker gene. Chromosomal vector carries acceptor loxP cassette and the other part of the drug-resistant marker gene. After co-transfection of the donor vector and the Cre expression plasmid into the host cells, site-specific insertion is correctly selected by reconstruction of the drug-resistant marker gene. In addition to dominant selectable markers like neo (Fukushige and Sauer 1992), hypoxanthine phosphoribosyl transferase (HPRT) mini-gene cassette (Ramírez-Solis et al. 1995) is useful in HPRT-deficient host cells, which are easily isolated as 6-thioguanine (6-TG) resistant mutants. One application of chromosomal vector is simultaneous transfer of multiple genes into target cells. Since the prototype chromosomal vector possesses a single-acceptor loxP site, multiple genes should be unified in a donor vector such as BAC or PAC by conventional in vitro recombinant DNA technique. Processing of BAC or PAC for unifying multiple genes is, however, laborious because of their low copy number in host $E$. coli and of their large size beyond the fractionation range in gel electrophoresis.

An alternative to unifying multiple genes in a single donor vector is increase of acceptor site on chromosomal vector by utilizing other integrase systems capable of site-specific insertion of donor vector. Application of several integrase systems derived from different microorganisms had been reported in mammalian cells (Fogg et al. 2014). Yamaguchi et al. made a HAC vector carrying five acceptor sites for utilizing FLP, $\varphi \mathrm{C} 31$, R4, TP901-1, and Bxb1 integrases (Yamaguchi et al. 2011), which was designated as MIHAC. In the MI-HAC, a pair of promoters for a selection marker gene and acceptor site for an integrase was tandemly placed, while in a donor vector, a gene of interest was placed along with promoter-less drug-resistant gene. Theoretically, up to five different genes of interest could be loaded onto the MI-HAC by reconstruction of the selection marker gene by site-specific integration of the donor vector.

In the case of a bottom-up HAC (25-4 vector), since multiple lox 71 sites were integrated into the HAC, a lox66 sequence in the donor vector containing desired gene is useful for the sequential insertion of multiple desired genes into the HAC (Hasegawa et al. 2014). A drawback of this system is that the stability and germline transmission efficiency of the HAC was decreased after second gene insertion potentially due to the structural changes of the HAC.

In case of top-down HAC (49B(A)A9 minichromosome), iterative site-specific integration (ISSI) system on the 49B(A)A9 mini-chromosome derived from human Y chromosome were developed (DafhnisCalas et al. 2005). ISSI combined the activities of $\varphi \mathrm{C} 31$ integrase and Cre recombinase to enable the iterative and serial integration of transgenic DNA sequences.

However, during the chromosome engineering processes for the construction of the chromosomal vector itself, several selection marker genes had been already used, and a limited number of selection markers are available for further integration of the donor vector into the chromosomal vector. To overcome the problem of this scarcity in selection markers, of relevance to loading of multiple genes to mammalian artificial chromosome, another example has been reported (Tóth et al. 2014). This approach is based on a protocol by which an artificial chromosome was made utilizing incidental chromosome rearrangement associated with the transfection of satellite DNA into murine cells (deJong et al. 1999). The artificial chromosome vector utilizes modified R4 integrase derived from lambda phage for target integration of donor vectors into the acceptor site on the artificial chromosome. By placing between two loxP sites in the donor vector, the selection marker gene can be excised by Cre enzyme expression after loading of a gene of interest, which allows sequential loading of different genes in other acceptor sites on the artificial chromosome vector. A drawback of this system is that the number of acceptor sites and loaded gene is not predictable. 
To overcome the problem of this complicated geneloading protocol on the chromosomal vectors, a simple method for the simultaneous or sequential integration of multiple gene-loading vectors into a HAC vector, designated as the simultaneous or sequential integration of multiple gene-loading vectors (SIM) system, was reported (Suzuki et al. 2014). In the SIM system, simultaneous integration is attained by stepwise nested insertion of gene-loading vector by different integrases. Sequential integration is attained by the shedding of formerly reconstructed marker gene, caused by targeted insertion of an ensuing donor vector. These are achieved by elaborate placement of target sequence for integration and smart utilization of splicing acceptor and donor cassettes to splice out the acceptor site for the next reaction embedded between the front and rear half of the selection marker genes. A prominent feature of this system is that multiple gene-loading vectors can be integrated by the cycling use of only two selection marker genes at most. Thus, the SIM system on HAC/ MAC vectors is very useful and expected to expand the applicability of HAC/MAC vectors for multiple gene expression study, because SIM system can be applied to any HAC/MAC with a 5'HPRT-type cassette.

\section{Expression of genes in HAC/MAC}

Functional analyses

The functions of novel genes have been deduced mainly in experiments using viral transfection or integrative transfection of BAC or yeast artificial chromosome (YAC) vectors, where often the gene cannot be expressed at a physiological level because the gene copy number is not regulated and a BAC/YAC transgene randomly integrates into the host genome. The HACs and MACs described above provide a way to overcome these problems (Oshimura et al. 2013). Genes that have been loaded in various types of HACs/MACs are listed in Table 2. The alphoid ${ }^{\text {tetO }}-\mathrm{HAC}$, which possesses a conditional centromere, provides a particularly effective way to control the phenotypic changes attributed to the expression of HAC-encoded genes. A battery of functional tests was performed to demonstrate the expression of the NBS1 and VHL genes from the HAC at physiological levels, which showed that phenotypes arising from stable gene expression can be reversed when cells are "cured" of the HAC by inactivating its kinetochore in proliferating cell populations (Kouprina et al. 2014). Thus, this type of HAC should be suitable for studies of gene function. Exploiting the potential of HACs for further gene transfer and expression studies is the first step for subsequent proof-of-concept studies (Kim et al. 2011). Most recently, the HAC could be used for functional study of BRCA-1 tumor suppressor gene (Kononenko et al. 2014). Furthermore, two different HAC, a stable 21HAC and a removable tet-O HAC provides a unique bi-HAC vector system for transient gene expression (Iida et al. 2014).

Relationship between gene copy number and gene expression in HACs

A HAC vector, FVIII-HAC, carrying the human factor VIII (FVIII) cDNA, was constructed and inserted into $\mathrm{CHO}$ cells (Kurosaki et al. 2011). One or more copies of the FVIII gene on the HAC were expressed in a copy number-dependent manner in the $\mathrm{CHO}$ cells. The HAC with 16 copies of FVIII, FVIII (16)-HAC, was transferred from $\mathrm{CHO}$ hybrids into a human immortalized mesenchymal stem cell (hiMSC) line by MMCT. The expression levels of HAC-derived FVIII transgene products were compared with transfected FVIII plasmids. The results showed that the expression levels of the former were consistent with those of the original clones, even after 50 population doublings (PDLs), whereas the latter showed a remarkable decrease in expression despite a consistent DNA content. These findings showed that the gene on the HAC was resistant to gene silencing. As an example of the application for protein expression, SATAC was effectively used to rapidly generate stable $\mathrm{CHO}$ cell lines expressing high levels of monoclonal antibody (Kennard et al. 2009a; Kennard et al. 2009b). Thus, the HAC/MAC/SATACmediated therapeutic gene expression system may be a powerful tool for stable expression of transgenes and possibly for industrial production of gene products.

Tissue-specific expression

The feasibility of lineage-specific transgene expression by the HAC vector was assessed in an in vitro differentiation system with an MSC cell line, hiMSC, which has the potential for osteogenic, chondrogenic, and adipogenic differentiation (Ren et al. 2005; Suda et al. 2006). An EGFP gene driven by a promoter for the osteogenic lineage-specific osteopontin (OPN) gene 


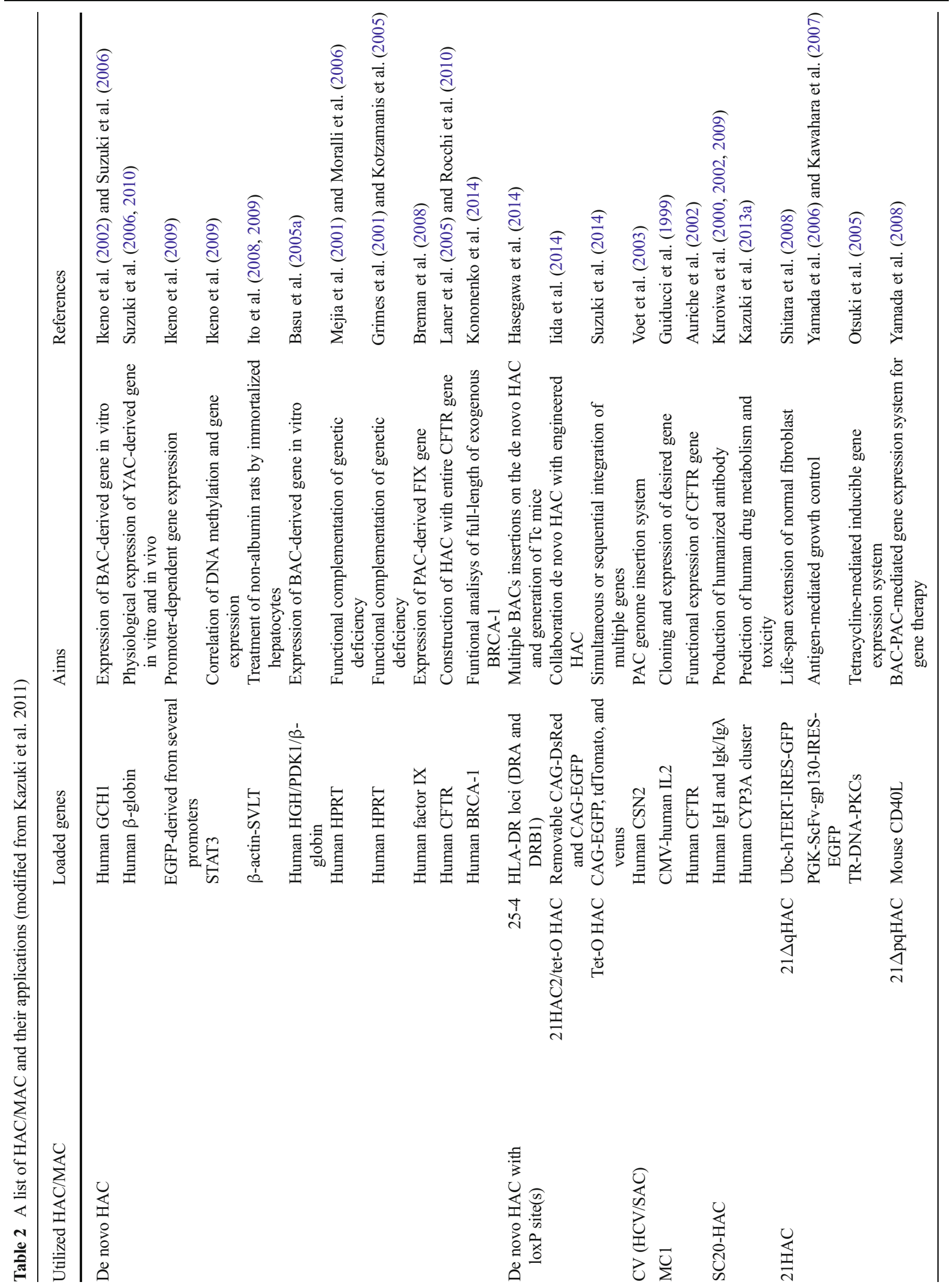




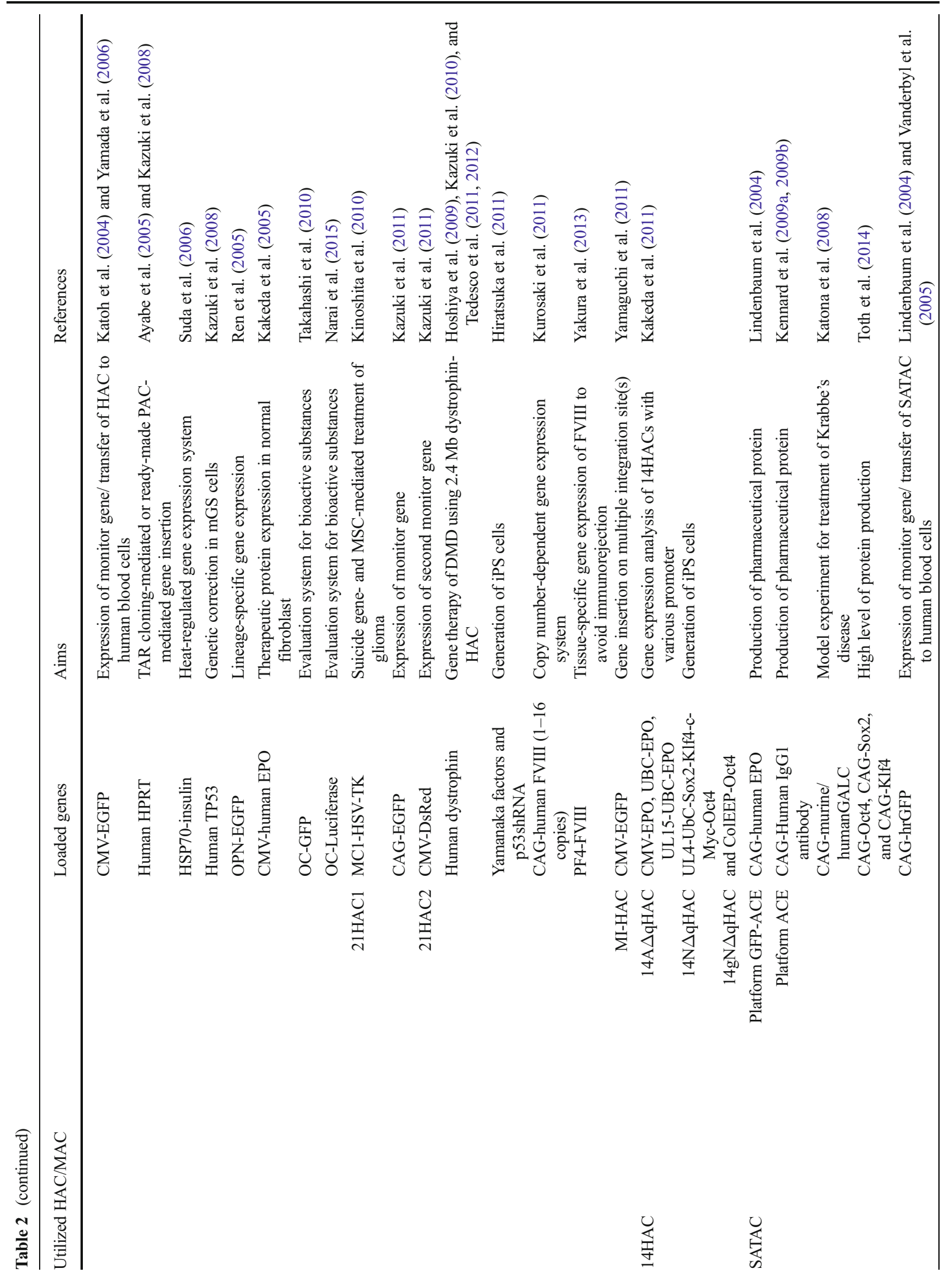




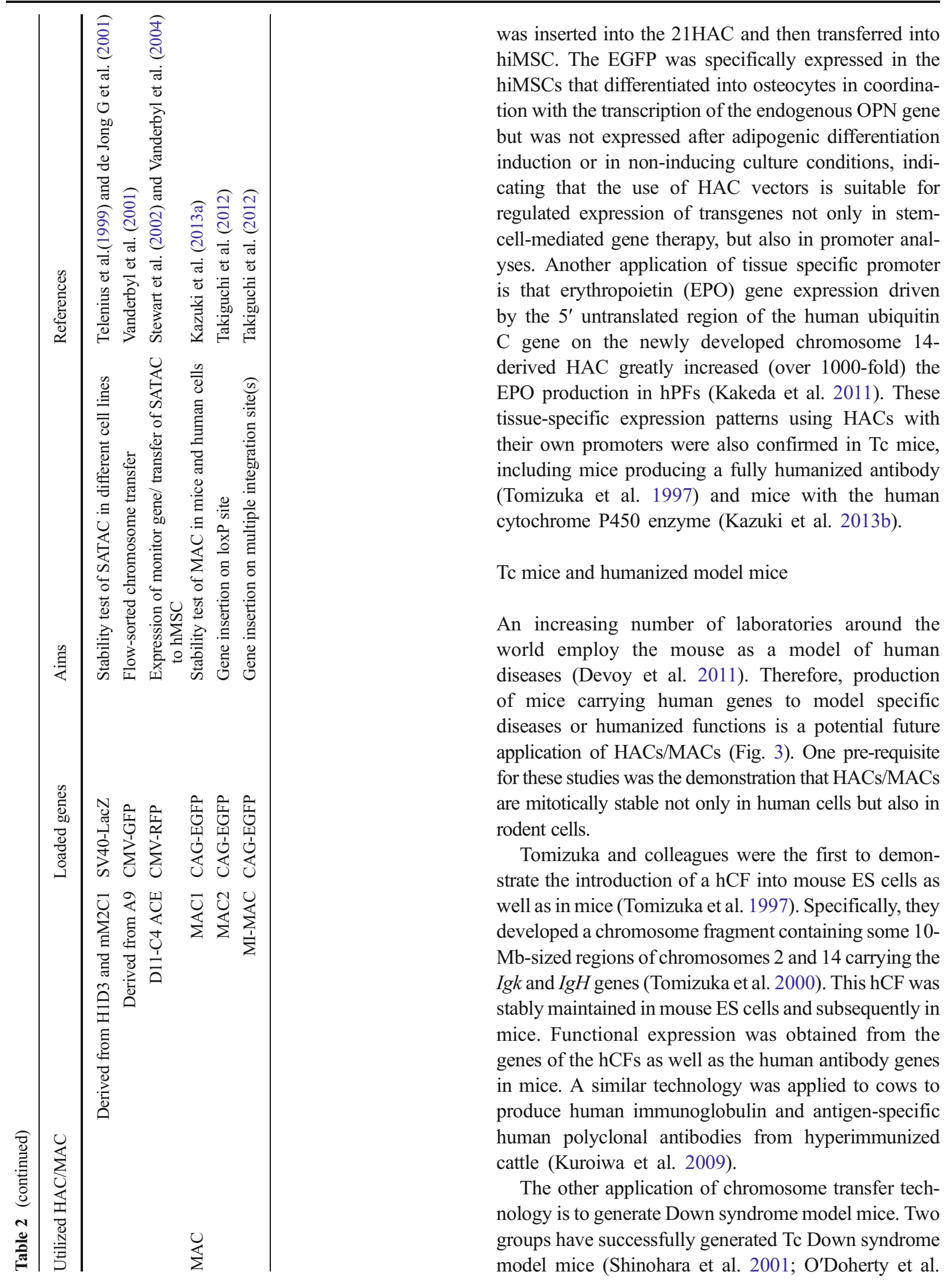




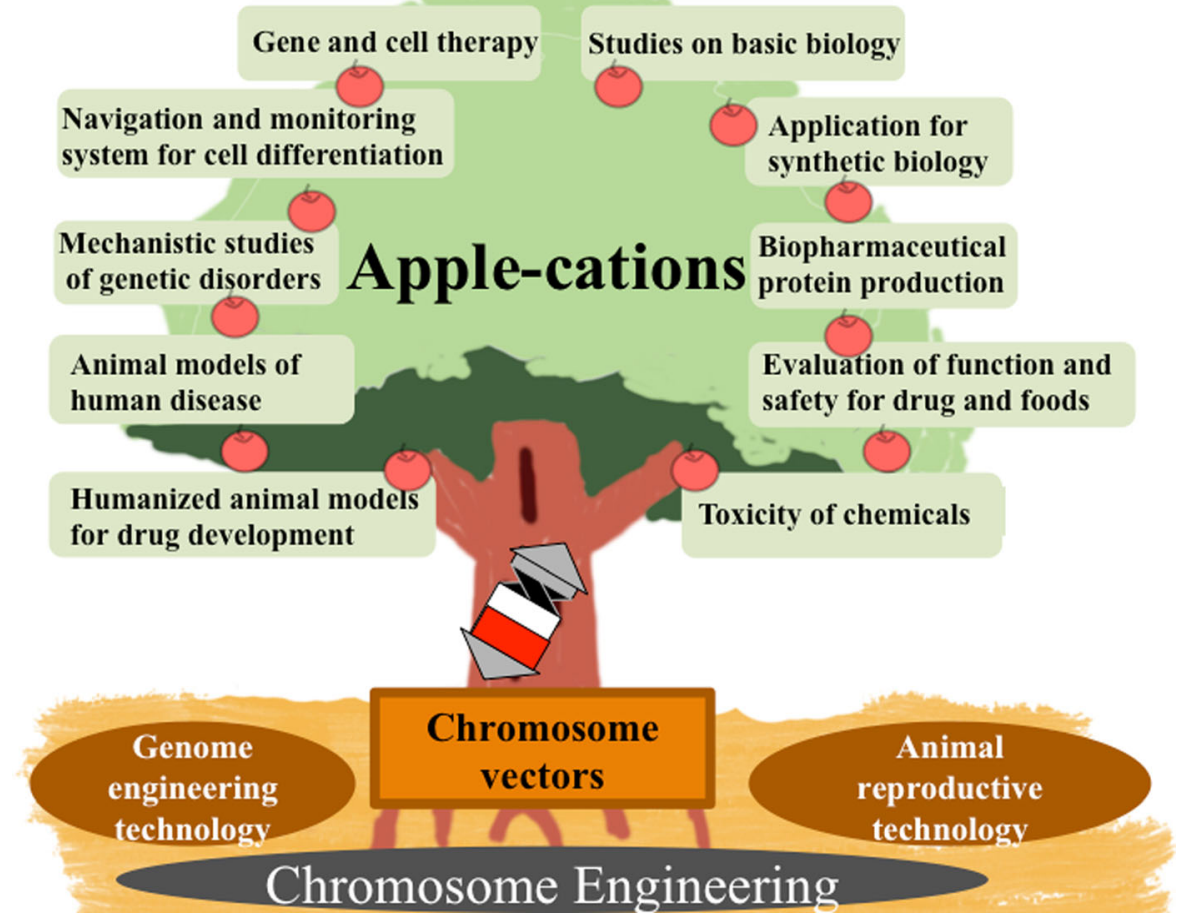

Fig. 3 Fruits from applications of chromosome vectors in the bio-medical field

2005). These mice contain an extra human Chr. 21 and show cardiac abnormalities and behavioral impairment similar to patients with Down syndrome.

Another example is a humanized mouse with a human CYP3A cluster (Kazuki et al. 2013b). Human CYP3A is the most abundant P450 isozyme present in the human liver and small intestine, which metabolizes around $50 \%$ of the medical drugs on the market. The human CYP3A subfamily comprises four members (CYP3A4, CYP3A5, CYP3A7, CYP3A43) encoded by a region on human chromosome 7 . The introduction of a HAC containing the entire human genomic CYP3A locus recapitulates tissue- and stage-specific expression of human CYP3A genes and xenobiotic metabolism in mice. Thus, this system can be also used for generating Tc mice carrying a wide variety of other human metabolic genes. Since allelic expression imbalance of the human CYP3A4 gene was reported (Hirota et al. 2004), the desired two alleles converted from a CYP3A4 by the genome-editing technologies such as the CRISPR/Cas9 system can be transferred to a mouse to confirm the phenomenon observed in humans. Thus, the combination of HAC/MAC containing desired large genomic cluster and the genome editing will facilitate the generation of humanized animals.
The creation of transgenic mice using de novo constructed HACs carrying human beta-globin (Suzuki et al. 2006), GCH1 (Suzuki et al. 2006), CSN2 (Voet et al. 2003), and HLA (Hasegawa et al. 2014) genes also succeeded. These studies demonstrated that the HACs have been transmitted through the mouse germline, thereby providing evidence of the meiotic stability of the HACs in vivo. Thus, the proven availability of HAC vectors to carry certain genes in animals provides an opportunity to develop specific human disease models, and also to commercially produce therapeutic products. HAC/MAC-based transgenesis can be used to identify genes responsible for recessive phenotypes by complementation or expression of dominant phenotypes. This approach is also applicable to the study of the complex genomic network in a near endogenous context.

Genes in HACs/MACs and medical applications

Gene therapy has been envisioned to provide a direct and permanent correction of genetic defects. To achieve the desired effects, therapeutic genes need to be carried by safe and effective vectors that can deliver foreign genes to specific cells and thereafter sustain their expression in a physiologically regulated fashion. 
Gene delivery vectors with the following properties may further add to the applications for gene and cell therapies: (1) high transfection efficiency; (2) longterm stable maintenance in host cells without integration into the host genome; (3) appropriate levels of spatial and temporal expression of therapeutic genes in specifically desired cells; (4) no risk of cellular transformation or stimulation of the host's immune system; and (5) a system to safeguard against tumor formation. Although a number of different approaches have been attempted to achieve efficient gene transfer and long-term gene expression, this challenging task remains unfulfilled because all current methods have certain limitations, including transient expression, consequent toxicity, undesired immunological response, integration of target genes into the host cell genome, and transcriptional silencing. An alternative solution to these problems could be the use of HAC vectors. For example, the advantages of HAC vectors have been demonstrated for reprogramming mouse embryonic fibroblasts (MEFs) into iPS cells (Hiratsuka et al. 2011). A HAC carrying four reprogramming factors with a $553-$ knockdown cassette (iHAC) efficiently reprogrammed MEFs. Global gene expression patterns showed that the iHAC generated relatively uniform iPS cells. Under nonselecting conditions, iHAC-free iPS cells were isolated as cells that spontaneously lost iHAC2. Analyses of pluripotent markers, teratomas, and chimeras confirmed that these iHAC-free iPS cells were pluripotent. Moreover, iHAC-free iPS cells with a re-introduced HAC encoding Herpes Simplex virus thymidine kinase were eliminated by ganciclovir exposure, indicating that the HAC safeguard system functioned in iPS cells. Thus, the HAC vector could generate uniform, integration-free iPS cells with a built-in safeguard system (Uno et al. 2014).

Another example is HAC utility for gene therapy for Duchenne muscular dystrophy (DMD). DMD gene was newly loaded on 21HAC2 (Kazuki et al. 2010). DMD is caused by dysfunction of the dystrophin gene (Koenig et al. 1988). Since some DMD patients show a large deletion in the dystrophin gene, these defects cannot be corrected by exon-skipping approaches (Odom et al. 2007; Tedesco and Cossu 2012). Although several vectors have been developed for DMD gene therapy, no episomal vectors containing the entire dystrophin genomic region have been reported owing to the extremely large size of this region $(2.4 \mathrm{Mb})$ (Koenig et al. 1987). Thus, a 21HAC vector containing the entire dystrophin genomic region
(DYS-HAC) has been developed for potential application in DMD gene therapy (Hoshiya et al. 2009). The complete correction of a genetic deficiency was shown in iPS cells derived from DMD model (mdx) mice and a human DMD patient using the DYS-HAC. In addition, the DYS-HAC isoforms were verified in cardiomyocytes differentiated from iPS cells, which are derived from DMD patients (Zatti et al. 2014). More details are described by Tedesco in this special issue (Kazuki et al. 2010; Uno et al. 2014; Tedesco and Cossu 2012; Tedesco et al. 2011; Tedesco et al. 2012).

The other example is Globoid cell leukodystrophy (also known as Krabbe's disease), which is an autosomal recessively inherited disease caused by a deficiency of galactocerebrosidase (GALC), a lysosomal enzyme that degrades galactosylceramide, a major glycolipid component of myelin and myelin-forming cells (Katona et al. 2008). In an experimental model for the treatment of Krabbe's disease, Katona and colleagues showed that the life span was increased in chimeric model mice when wild-type ES cells with a SATAC containing the human GALC gene was microinjected into the model mousederived blastocysts. However, the life-span extension is possibly attributable to the genomic copy of the GALC gene present in the wild-type ES cells.

Finally, advances in the efficiency of methods used for the differentiation and purification of stem cells, including ES and iPS cells, are anticipated, and the application of these methods to ES/iPS cells combined with HAC vector systems may enable the development of more sophisticated gene therapies. Thus, stem cells, potentially derived from multiple sources, combined with HAC-mediated gene delivery, should permit safe treatment of various genetic defects. The next step in the future of gene therapy is to demonstrate functional restoration and safety in vivo using large animal models such as dogs and monkeys.

\section{Conclusions}

The chromosomal vector systems offer complementary and desirable characteristics for use as gene delivery vectors to overcome various problems in existing viral and non-viral vector systems. The most important property of HAC and MAC vectors is that they can express entire complex signaling pathways under their normal physiological regulation, which is of great potential benefit. Stem cells possess two characteristic features: the ability for self- 
renewal and the ability for multi-lineage differentiation. A number of other applications of HACs/MACs in addition to gene therapy and animal models are possible (Fig. 3). For example, HACs can be used for basic research on human cells and gene therapy, and MACs for basic research on mouse cells and Tc mice. There is also increasing interest in HACs/MACs as a potential platform for developing more sophisticated control of mammalian cells in the new area of "Synthetic Biology," e.g., studying the RNA world. Thus, HACs/MACs may be designated as "multipotent vectors."

A combination of chromosome engineering technologies and genome-editing technologies should facilitate the applications to bio-medical challenges (Fig. 3). Genome editing using ZFNs, transcription activatorlike effector nucleases (TALENs), or CRISPR/Cas9 are efficient strategies for the modification of desired endogenous genes in cells and organisms (Hsu et al. 2014; Sander and Joung 2014). In principle, a combination of HAC/MAC/chromosome transfer and genome-editing technologies has several advantages for the generation of humanized animal models and disease models as well as for basic MMCT and chromosome engineering technologies. Possible application of the combined technologies was discussed in the text. Genome-editing technologies have been applied to many organisms due to the simple mRNA and plasmid transfection techniques. To our knowledge, HAC/MAC have never been transferred to plants and insects. If HAC/MAC can be transferred to several organisms in addition to mammalian cells, $\mathrm{HAC} /$ MAC may be widely utilized in many research areas such as genome editing. Recently, we developed fusion chromosomes of human-plants via whole cell fusion technique (unpublished data). These chromosomes may be used as shuttle vectors or multipurpose vectors, if they segregate in plant and mammalian cells. Shuttle chromosome vectors that can be transferred to any organisms and segregate in them need to be developed.

Open Access This article is distributed under the terms of the Creative Commons Attribution License which permits any use, distribution, and reproduction in any medium, provided the original author(s) and the source are credited.

\section{References}

Abe S, Tanaka H, Notsu T, Horike S, Fujisaki C, Qi DL, Ohhira T, Gilley D, Oshimura M, Kugoh H (2010) Localization of an hTERT repressor region on human chromosome 3 p21.3 using chromosome engineering. Genome Integr 1:6
Anderson BD, Nakamura T, Russell SJ, Peng KW (2004) High CD46 receptor density determines preferential killing of tumor cells by oncolytic measles virus. Cancer Res 64(14): 4919-4926

Auriche C, Carpani D, Conese M, Caci E, Zegarra-Moran O, Donini P, Ascenzioni F (2002) Functional human CFTR produced by a stable minichromosome. EMBO Rep 3(9):862-868

Ayabe F, Katoh M, Inoue $\mathrm{T}$, Kouprina N, Larionov V, Oshimura M (2005) A novel expression system for genomic DNA loci using a human artificial chromosome vector with transformation-associated recombination cloning. J Hum Genet 50(11):592-599

Basu J, Compitello G, Stromberg G, Willard HF, Van Bokkelen G (2005a) Efficient assembly of de novo human artificial chromosomes from large genomic loci. BMC Biotechnol 5:21

Basu J, Stromberg G, Compitello G, Willard HF, Van Bokkelen G (2005b) Rapid creation of BAC-based human artificial chromosome vectors by transposition with synthetic alphasatellite arrays. Nucleic Acids Res 33(2):587-596

Bird A (2007) Perceptions of epigenetics. Nature 447(7143): 396-398

Breman AM, Steiner CM, Slee RB, Grimes BR (2008) Input DNA ratio determines copy number of the $33 \mathrm{~kb}$ factor IX gene on de novo human artificial chromosomes. Mol Ther 16(2):315-323

Brown KE, Barnett MA, Burgtorf C, Shaw P, Buckle VJ, Brown WR (1994) Dissecting the centromere of the human Y chromosome with cloned telomeric DNA. Hum Mol Genet 3(8): $1227-1237$

Buerstedde JM, Takeda S (1991) Increased ratio of targeted to random integration after transfection of chicken $\mathrm{B}$ cell lines. Cell 67(1):179-188

Chen B, Gilbert LA, Cimini BA, Schnitzbauer J, Zhang W, Li GW, Park J, Blackburn EH, Weissman JS, Qi LS, Huang B (2013) Dynamic imaging of genomic loci in living human cells by an optimized CRISPR/Cas system. Cell 155(7):1479-1491

Cheung AK, Lung HL, Ko JM, Cheng Y, Stanbridge EJ, Zabarovsky ER, Nicholls JM, Chua D, Tsao SW, Guan XY, Lung ML (2009) Chromosome 14 transfer and functional studies identify a candidate tumor suppressor gene, mirror image polydactyly 1 , in nasopharyngeal carcinoma. Proc Natl Acad Sci U S A 106(34):14478-14483

Crenshaw AH, Shay JW, Murrell LR (1981) Colcemid-induced micronucleation in cultured human cells. J Ultrastruct Res 75(2):179-186

Dafhnis-Calas F, Xu Z, Haines S, Malla SK, Smith MC, Brown WR (2005) Iterative in vivo assembly of large and complex transgenes by combining the activities of phiC31 integrase and Cre recombinase. Nucleic Acids Res 33(22):e189

de Jong G, Telenius A, Vanderbyl S, Meitz A, Drayer J (2001) Efficient in-vitro transfer of a $60-\mathrm{Mb}$ mammalian artificial chromosome into murine and hamster cells using cationic lipids and dendrimers. Chromosome Res 9(6):475-485

deJong G, Telenius AH, Telenius H, Perez CF, Drayer JI, Hadlaczky G (1999) Mammalian artificial chromosome pilot production facility: large-scale isolation of functional satellite DNA-based artificial chromosomes. Cytometry 35(2): 129-133

Devoy A, Bunton-Stasyshyn RK, Tybulewicz VL, Smith AJ, Fisher EM (2011) Genomically humanized mice: technologies and promises. Nat Rev Genet 13(1):14-20 
Dhiman N, Jacobson RM, Poland GA (2004) Measles virus receptors: SLAM and CD46. Rev Med Virol 14(4): 217-229

Doherty AMO, Fisher EMC (2003) Microcell-mediated chromosome transfer (MMCT): small cells with huge potential. Mamm Genome 14(9):583-592

Ege T, Ringertz NR (1974) Preparation of microcells by enucleation of micronucleate cells. Exp Cell Res 87(2):378-382

Farr CJ, Stevanovic M, Thomson EJ, Goodfellow PN, Cooke HJ (1992) Telomere-associated chromosome fragmentation: applications in genome manipulation and analysis. Nat Genet 2(4):275-282

Fogg PC, Colloms S, Rosser S, Stark M, Smith MC (2014) New applications for phage integrases. J Mol Biol 426(15): 2703-2716

Fournier RE, Ruddle FH (1977) Microcell-mediated transfer of murine chromosomes into mouse, Chinese hamster, and human somatic cells. Proc Natl Acad Sci U S A 74:319-323

Fukagawa T, Nogami M, Yoshikawa M, Ikeno M, Okazaki T, Takami Y, Nakayama T, Oshimura M (2004) Dicer is essential for formation of the heterochromatin structure in vertebrate cells. Nat Cell Biol 6(8):784-791

Fukushige S, Sauer B (1992) Genomic targeting with a positiveselection lox integration vector allows highly reproducible gene expression in mammalian cells. Proc Natl Acad Sci U S A 89(17):7905-7909

Golestani R, Pourfathollah AA, Moazzeni SM (2007) Cephalin as an efficient fusogen in hybridoma technology: can it replace poly ethylene glycol? Hybridoma (Larchmt) 26(5): 296-301

Grimes BR, Schindelhauer D, McGill NI, Ross A, Ebersole TA, Cooke HJ (2001) Stable gene expression from a mammalian artificial chromosome. EMBO Rep 2(10):910-914

Guiducci C, Ascenzioni F, Auriche C, Piccolella E, Guerrini AM, Donini P (1999) Use of a human minichromosome as a cloning and expression vector for mammalian cells. Hum Mol Genet 8(8):1417-1424

Harrington JJ, Van Bokkelen G, Mays RW, Gustashaw K, Willard HF (1997) Formation of de novo centromeres and construction of first-generation human artificial microchromosomes. Nat Genet 15(4):345-355

Hasegawa, Y., Ishikura, T., Hasegawa, T., Watanabe, T., Suzuki, J., Nakayama, M., Okamura, Y., Okazaki, T., Koseki, H., Ohara, O., Ikeno, M. and Masumoto, H. (2014) Generating a transgenic mouse line stably expressing human MHC surface antigen from a HAC carrying multiple genomic BACs. Chromosoma

Heller R, Brown KE, Burgtorf C, Brown WR (1996) Minichromosomes derived from the human $\mathrm{Y}$ chromosome by telomere directed chromosome breakage. Proc Natl Acad Sci U S A 93(14):7125-7130

Hiraoka K, Yamamoto S, Otsuru S, Nakai S, Tamai K, Morishita R, Ogihara T, Kaneda Y (2004) Enhanced tumor-specific long-term immunity of hemagglutinating [correction of hemaggluttinating] virus of Japan-mediated dendritic celltumor fused cell vaccination by coadministration with $\mathrm{CpG}$ oligodeoxynucleotides. J Immunol 173(7):4297-4307

Hiratsuka M, Uno N, Ueda K, Kurosaki H, Imaoka N, Kazuki K, Ueno E, Akakura Y, Katoh M, Osaki M, Kazuki Y, Nakagawa M, Yamanaka S, Oshimura M (2011) Integration-free iPS cells engineered using human artificial chromosome vectors. Plos One 6(10)
Hirota T, Ieiri I, Takane H, Maegawa S, Hosokawa M, Kobayashi K, Chiba K, Nanba E, Oshimura M, Sato T, Higuchi S, Otsubo K (2004) Allelic expression imbalance of the human CYP3A4 gene and individual phenotypic status. Hum Mol Genet 13(23):2959-2969

Horibata K, Iwamoto Y, Kuraoka I, Jaspers NG, Kurimasa A, Oshimura M, Ichihashi M, Tanaka K (2004) Complete absence of Cockayne syndrome group $\mathrm{B}$ gene product gives rise to UV-sensitive syndrome but not Cockayne syndrome. Proc Natl Acad Sci U S A 101(43):15410-15415

Horike S, Mitsuya K, Meguro M, Kotobuki N, Kashiwagi A, Notsu T, Schulz TC, Shirayoshi Y, Oshimura M (2000) Targeted disruption of the human LIT1 locus defines a putative imprinting control element playing an essential role in Beckwith-Wiedemann syndrome. Hum Mol Genet 9(14): 2075-2083

Hoshiya H, Kazuki Y, Abe S, Takiguchi M, Kajitani N, Watanabe Y, Yoshino T, Shirayoshi Y, Higaki K, Messina G, Cossu G, Oshimura M (2009) A highly stable and nonintegrated human artificial chromosome (HAC) containing the $2.4 \mathrm{Mb}$ entire human dystrophin gene. Mol Ther 17(2):309-317

Hsu PD, Lander ES, Zhang F (2014) Development and applications of CRISPR-Cas9 for genome engineering. Cell 157(6): $1262-1278$

Ichikawa T, Nihei N, Suzuki H, Oshimura M, Emi M, Nakamura Y, Hayata I, Isaacs JT, Shimazaki J (1994) Suppression of metastasis of rat prostatic cancer by introducing human chromosome 8. Cancer Res 54(9):2299-2302

Iida Y, Kazuki Y, Hayashi M, Ueda Y, Hasegawa M, Kouprina N, Larionov V, Oshimura M (2014) Bi-HAC vector system toward gene and cell therapy. ACS Synth Biol 3(2):83-90

Iida Y, Kim JH, Kazuki Y, Hoshiya H, Takiguchi M, Hayashi M, Erliandri I, Lee HS, Samoshkin A, Masumoto H, Earnshaw WC, Kouprina N, Larionov V, Oshimura M (2010) Human artificial chromosome with a conditional centromere for gene delivery and gene expression. DNA Res 17(5):293-301

Ikeno M, Grimes B, Okazaki T, Nakano M, Saitoh K, Hoshino H, McGill NI, Cooke H, Masumoto H (1998) Construction of YAC-based mammalian artificial chromosomes. Nat Biotechnol 16(5):431-439

Ikeno M, Inagaki H, Nagata K, Morita M, Ichinose H, Okazaki T (2002) Generation of human artificial chromosomes expressing naturally controlled guanosine triphosphate cyclohydrolase I gene. Genes Cells 7(10):1021-1032

Ikeno M, Suzuki N, Hasegawa Y, Okazaki T (2009) Manipulating transgenes using a chromosome vector. Nucleic Acids Res 37(6):e44

Ito M, Ikeno M, Nagata H, Yamamoto T, Hiroguchi A, Fox IJ, Miyakawa S (2009) Treatment of nonalbumin rats by transplantation of immortalized hepatocytes using artificial human chromosome. Transplant Proc 41(1):422-424

Ito $\mathrm{M}$, Ito $\mathrm{R}$, Yoshihara $\mathrm{D}$, Ikeno $\mathrm{M}$, Kamiya M, Suzuki N, Horiguchi A, Nagata H, Yamamoto T, Kobayashi N, Fox IJ, Okazaki T, Miyakama S (2008) Immortalized hepatocytes using human artificial chromosome. Cell Transplant 17(1-2): $165-171$

Joung JK, Sander JD (2013) TALENs: a widely applicable technology for targeted genome editing. Nat Rev Mol Cell Biol 14(1):49-55

Kai Y, Wang CC, Kishigami S, Kazuki Y, Abe S, Takiguchi M, Shirayoshi Y, Inoue T, Ito H, Wakayama T, Oshimura M 
(2009) Enhanced apoptosis during early neuronal differentiation in mouse ES cells with autosomal imbalance. Cell Res 19(2):247-258

Kakeda M, Hiratsuka M, Nagata K, Kuroiwa Y, Kakitani M, Katoh M, Oshimura M, Tomizuka K (2005) Human artificial chromosome (HAC) vector provides long-term therapeutic transgene expression in normal human primary fibroblasts. Gene Ther 12(10):852-856

Kakeda M, Nagata K, Osawa K, Matsuno H, Hiratsuka M, Sano A, Okazaki A, Shitara S, Nishikawa S, Masuya A, Hata T, Wako S, Osaki M, Kazuki Y, Oshimura M, Tomizuka K (2011) A new chromosome 14-based human artificial chromosome (HAC) vector system for efficient transgene expression in human primary cells. Biochem Biophys Res Commun 415(3):439-444

Katoh M, Ayabe F, Norikane S, Okada T, Masumoto H, Horike S, Shirayoshi Y, Oshimura M (2004) Construction of a novel human artificial chromosome vector for gene delivery. Biochem Biophys Res Commun 321(2):280-290

Katoh M, Kazuki Y, Kazuki K, Kajitani N, Takiguchi M, Nakayama Y, Nakamura T, Oshimura M (2010) Exploitation of the interaction of measles virus fusogenic envelope proteins with the surface receptor CD46 on human cells for microcell-mediated chromosome transfer. BMC Biotechnol 10

Katona RL, Sinkó I, Holló G, Szucs KS, Praznovszky T, Kereso J, Csonka E, Fodor K, Cserpán I, Szakál B, Blazsó P, Udvardy A, Hadlaczky G (2008) A combined artificial chromosomestem cell therapy method in a model experiment aimed at the treatment of Krabbe's disease in the Twitcher mouse. Cell Mol Life Sci 65(23):3830-3838

Kawahara M, Inoue T, Ren X, Sogo T, Yamada H, Katoh M, Ueda H, Oshimura M, Nagamune T (2007) Antigen-mediated growth control of hybridoma cells via a human artificial chromosome. Biochim Biophys Acta 1770(2):206-212

Kazuki K, Takehara S, Uno N, Imaoka N, Abe S, Takiguchi M, Hiramatsu K, Oshimura M, Kazuki Y (2013a) Highly stable maintenance of a mouse artificial chromosome in human cells and mice. Biochem Biophys Res Commun 442(1-2): 44-50

Kazuki Y, Hiratsuka M, Takiguchi M, Osaki M, Kajitani N, Hoshiya H, Hiramatsu K, Yoshino T, Kazuki K, Ishihara C, Takehara S, Higaki K, Nakagawa M, Takahashi K, Yamanaka S, Oshimura M (2010) Complete genetic correction of iPS cells from Duchenne muscular dystrophy. Mol Ther 18(2):386-393

Kazuki Y, Hoshiya H, Kai Y, Abe S, Takiguchi M, Osaki M, Kawazoe S, Katoh M, Kanatsu-Shinohara M, Inoue K, Kajitani N, Yoshino T, Shirayoshi Y, Ogura A, Shinohara T, Barrett JC, Oshimura M (2008) Correction of a genetic defect in multipotent germline stem cells using a human artificial chromosome. Gene Ther 15(8):617-624

Kazuki Y, Hoshiya H, Takiguchi M, Abe S, Iida Y, Osaki M, Katoh M, Hiratsuka M, Shirayoshi Y, Hiramatsu K, Ueno E, Kajitani N, Yoshino T, Kazuki K, Ishihara C, Takehara S, Tsuji S, Ejima F, Toyoda A, Sakaki Y, Larionov V, Kouprina N, Oshimura M (2011) Refined human artificial chromosome vectors for gene therapy and animal transgenesis. Gene Ther 18(4):384-393

Kazuki Y, Kobayashi K, Aueviriyavit S, Oshima T, Kuroiwa Y, Tsukazaki Y, Senda N, Kawakami H, Ohtsuki S, Abe S,
Takiguchi M, Hoshiya H, Kajitani N, Takehara S, Kubo K, Terasaki T, Chiba K, Tomizuka K, Oshimura M (2013b) Trans-chromosomic mice containing a human CYP3A cluster for prediction of xenobiotic metabolism in humans. Hum Mol Genet 22(3):578-592

Kazuki Y, Oshimura M (2011) Human artificial chromosomes for gene delivery and the development of animal models. Mol Ther 19(9):1591-1601

Kazuki Y, Yakura Y, Abe S, Osaki M, Kajitani N, Kazuki K, Takehara S, Honma K, Suemori H, Yamazaki S, Sakuma T, Toki T, Shimizu R, Nakauchi H, Yamamoto T, Oshimura M (2014) Down syndrome-associated haematopoiesis abnormalities created by chromosome transfer and genome editing technologies. Sci Rep 4:6136

Kennard ML, Goosney DL, Monteith D, Roe S, Fischer D, Mott J (2009a) Auditioning of CHO host cell lines using the artificial chromosome expression (ACE) technology. Biotechnol Bioeng 104(3):526-539

Kennard ML, Goosney DL, Monteith D, Zhang L, Moffat M, Fischer D, Mott J (2009b) The generation of stable, high MAb expressing $\mathrm{CHO}$ cell lines based on the artificial chromosome expression (ACE) technology. Biotechnol Bioeng 104(3):540-553

Kim JH, Kononenko A, Erliandri I, Kim TA, Nakano M, Iida Y, Barrett JC, Oshimura M, Masumoto H, Earnshaw WC, Larionov V, Kouprina N (2011) Human artificial chromosome (HAC) vector with a conditional centromere for correction of genetic deficiencies in human cells. Proc Natl Acad Sci U S A 108(50):20048-20053

Kinoshita Y, Kamitani H, Mamun MH, Wasita B, Kazuki Y, Hiratsuka M, Oshimura M, Watanabe T (2010) A gene delivery system with a human artificial chromosome vector based on migration of mesenchymal stem cells towards human glioblastoma HTB14 cells. Neurol Res 32(4):429-437

Koenig M, Hoffman EP, Bertelson CJ, Monaco AP, Feener C, Kunkel LM (1987) Complete cloning of the Duchenne muscular dystrophy (DMD) cDNA and preliminary genomic organization of the DMD gene in normal and affected individuals. Cell 50(3):509-517

Koenig M, Monaco AP, Kunkel LM (1988) The complete sequence of dystrophin predicts a rod-shaped cytoskeletal protein. Cell 53(2):219-228

Kononenko, A. V., Bansal, R., Lee, N. C., Grimes, B. R., Masumoto, H., Earnshaw, W. C., Larionov, V. and Kouprina, N. (2014) A portable BRCA1-HAC (human artificial chromosome) module for analysis of BRCA1 tumor suppressor function. Nucleic Acids Res

Kotzamanis G, Cheung W, Abdulrazzak H, Perez-Luz S, Howe S, Cooke H, Huxley C (2005) Construction of human artificial chromosome vectors by recombineering. Gene 351:29-38

Kouprina N, Ebersole T, Koriabine M, Pak E, Rogozin IB, Katoh M, Oshimura M, Ogi K, Peredelchuk M, Solomon G, Brown W, Barrett JC, Larionov V (2003) Cloning of human centromeres by transformation-associated recombination in yeast and generation of functional human artificial chromosomes. Nucleic Acids Res 31(3):922-934

Kouprina N, Tomilin AN, Masumoto H, Earnshaw WC, Larionov V (2014) Human artificial chromosome-based gene delivery vectors for biomedicine and biotechnology. Expert Opin Drug Deliv 11(4):517-535 
Kugoh H, Mitsuya K, Meguro M, Shigenami K, Schulz TC, Oshimura M (1999) Mouse A9 cells containing single human chromosomes for analysis of genomic imprinting. DNA Res 6(3):165-172

Kugoh H, Shigenami K, Funaki K, Barrett JC, Oshimura M (2003) Human chromosome 5 carries a putative telomerase repressor gene. Genes Chromosomes Cancer 36(1):37-47

Kurimasa A, Ohno K, Oshimura M (1993) Restoration of the cholesterol metabolism in $3 \mathrm{~T} 3$ cell lines derived from the sphingomyelinosis mouse (spm/spm) by transfer of a human chromosome 18. Hum Genet 92(2):157-162

Kuroiwa Y, Kasinathan P, Choi YJ, Naeem R, Tomizuka K, Sullivan EJ, Knott JG, Duteau A, Goldsby RA, Osborne BA, Ishida I, Robl JM (2002) Cloned transchromosomic calves producing human immunoglobulin. Nat Biotechnol 20(9):889-894

Kuroiwa Y, Kasinathan P, Sathiyaseelan T, Jiao JA, Matsushita H, Sathiyaseelan J, Wu H, Mellquist J, Hammitt M, Koster J, Kamoda S, Tachibana K, Ishida I, Robl JM (2009) Antigenspecific human polyclonal antibodies from hyperimmunized cattle. Nat Biotechnol 27(2):173-181

Kuroiwa Y, Tomizuka K, Shinohara T, Kazuki Y, Yoshida H, Ohguma A, Yamamoto T, Tanaka S, Oshimura M, Ishida I (2000) Manipulation of human minichromosomes to carry greater than megabase-sized chromosome inserts. Nat Biotechnol 18(10):1086-1090

Kurosaki H, Hiratsuka M, Imaoka N, Iida Y, Uno N, Kazuki Y, Ishihara C, Yakura Y, Mimuro J, Sakata Y, Takeya H, Oshimura M (2011) Integration-free and stable expression of FVIII using a human artificial chromosome. J Hum Genet 56(10):727-733

Laner A, Goussard S, Ramalho AS, Schwarz T, Amaral MD, Courvalin P, Schindelhauer D, Grillot-Courvalin C (2005) Bacterial transfer of large functional genomic DNA into human cells. Gene Ther 12(21):1559-1572

Lee NC, Kononenko AV, Lee HS, Tolkunova EN, Liskovykh MA, Masumoto H, Earnshaw WC, Tomilin AN, Larionov V, Kouprina N (2013) Protecting a transgene expression from the HAC-based vector by different chromatin insulators. Cell Mol Life Sci 70(19):3723-3737

Lindenbaum M, Perkins E, Csonka E, Fleming E, Garcia L, Greene A, Gung L, Hadlaczky G, Lee E, Leung J, MacDonald N, Maxwell A, Mills K, Monteith D, Perez CF, Shellard J, Stewart S, Stodola T, Vandenborre D, Vanderbyl S, Ledebur HC (2004) A mammalian artificial chromosome engineering system (ACE System) applicable to biopharmaceutical protein production, transgenesis and gene-based cell therapy. Nucleic Acids Res 32(21): e172

Ma H, Reyes-Gutierrez P, Pederson T (2013) Visualization of repetitive DNA sequences in human chromosomes with transcription activator-like effectors. Proc Natl Acad Sci U S A 110(52):21048-21053

Mandegar MA, Moralli D, Khoja S, Cowley S, Chan DY, Yusuf M, Mukherjee S, Blundell MP, Volpi EV, Thrasher AJ, James W, Monaco ZL (2011) Functional human artificial chromosomes are generated and stably maintained in human embryonic stem cells. Hum Mol Genet 20(15):2905-2913

Matsuura S, Weemaes C, Smeets D, Takami H, Kondo N, Sakamoto S, Yano N, Nakamura A, Tauchi H, Endo S, Oshimura M, Komatsu K (1997) Genetic mapping using microcell-mediated chromosome transfer suggests a locus for Nijmegen breakage syndrome at chromosome 8q21-24. Am J Hum Genet 60(6):1487-1494

Matsuura S, Tauchi H, Nakamura A, Kondo N, Sakamoto S, Endo S, Smeets D, Solder B, Belohradsky BH, Der Kaloustian VM, Oshimura M, Isomura M, Nakamura Y, Komatsu K (1998) Positional cloning of the gene for Nijmegen breakage syndrome. Nat Genet 19(2):179-181

Matsuura S, Matsumoto Y, Morishima K, Izumi H, Matsumoto H, Ito E, Tsutsui K, Kobayashi J, Tauchi H, Kajiwara Y, Hama S, Kurisu K, Tahara H, Oshimura M, Komatsu K, Ikeuchi T, Kajii T (2006) Monoallelic BUB1B mutations and defective mitotic-spindle checkpoint in seven families with premature chromatid separation (PCS) syndrome. Am J Med Genet A 140(4):358-367

Meaburn KJ, Parris CN, Bridger JM (2005) The manipulation of chromosomes by mankind: the uses of microcell-mediated chromosome transfer. Chromosoma 114(4):263-274

Meguro M, Kashiwagi A, Mitsuya K, Nakao M, Kondo I, Saitoh S, Oshimura M (2001) A novel maternally expressed gene, ATP10C, encodes a putative aminophospholipid translocase associated with Angelman syndrome. Nat Genet 28(1):19-20

Mejía JE, Willmott A, Levy E, Earnshaw WC, Larin Z (2001) Functional complementation of a genetic deficiency with human artificial chromosomes. Am J Hum Genet 69(2):315-326

Mitsuya K, Meguro M, Lee MP, Katoh M, Schulz TC, Kugoh H, Yoshida MA, Niikawa N, Feinberg AP, Oshimura M (1999) LIT1, an imprinted antisense RNA in the human KvLQT1 locus identified by screening for differentially expressed transcripts using monochromosomal hybrids. Hum Mol Genet 8(7):1209-1217

Miyanari Y, Ziegler-Birling C, Torres-Padilla ME (2013) Live visualization of chromatin dynamics with fluorescent TALEs. Nat Struct Mol Biol 20(11):1321-1324

Moralli D, Vagnarelli P, Bensi M, De Carli L, Raimondi E (2001) Insertion of a loxP site in a size-reduced human accessory chromosome. Cytogenet Cell Genet 94(3-4):113-120

Moralli D, Simpson KM, Wade-Martins R, Monaco ZL (2006) A novel human artificial chromosome gene expression system using herpes simplex virus type 1 vectors. EMBO Rep 7(9): 911-918

Nakamura T, Peng KW, Harvey M, Greiner S, Lorimer IA, James CD, Russell SJ (2005) Rescue and propagation of fully retargeted oncolytic measles viruses. Nat Biotechnol 23(2): 209-214

Nakamura T, Peng KW, Vongpunsawad S, Harvey M, Mizuguchi H, Hayakawa T, Cattaneo R, Russell SJ (2004) Antibodytargeted cell fusion. Nat Biotechnol 22(3):331-336

Nakano M, Cardinale S, Noskov VN, Gassmann R, Vagnarelli P, Kandels-Lewis S, Larionov V, Earnshaw WC, Masumoto H (2008) Inactivation of a human kinetochore by specific targeting of chromatin modifiers. Dev Cell 14(4):507-522

Nakayama Y, Uno N, Uno K, Mizoguchi Y, Komoto S, Kazuki Y, Nanba E, Nakayama Y, Uno N, Uno K, Mizoguchi Y, Komoto S, Kazuki Y, Nanba E, Inoue T, Oshimura M (2015) Recurrent micronucleation through cell cycle progression in the presence of microtubule inhibitors. Cell Struct Funct. doi:10.1247/csf.14005

Narai T, Katoh M, Inoue T, Taniguchi M, Kazuki K, Kazuki Y, Sato K, Kodani I, Ryoke K, Oshimura M (2015) Construction of a luciferase reporter system to monitor 
osteogenic differentiation of mesenchymal stem cells by using a mammalian artificial chromosome vector. Yonago Acta Med. in press

Narayanan K, Warburton PE (2003) DNA modification and functional delivery into human cells using Escherichia coli DH10B. Nucleic Acids Res 31(9):e51

Navaratnarajah CK, Leonard VH, Cattaneo R (2009) Measles virus glycoprotein complex assembly, receptor attachment, and cell entry. Curr Top Microbiol Immunol 329:59-76

Nawata H, Kashino G, Tano K, Daino K, Shimada Y, Kugoh H, Oshimura M, Watanabe M (2011) Dysregulation of gene expression in the artificial human trisomy cells of chromosome 8 associated with transformed cell phenotypes. PLoS One 6(9):e25319

Nishimoto A, Miura N, Horikawa I, Kugoh H, Murakami Y, Hirohashi S, Kawasaki H, Gazdar AF, Shay JW, Barrett JC, Oshimura M (2001) Functional evidence for a telomerase repressor gene on human chromosome 10p15.1. Oncogene 20(7):828-835

O'Doherty A, Ruf S, Mulligan C, Hildreth V, Errington ML, Cooke S, Sesay A, Modino S, Vanes L, Hernandez D, Linehan JM, Sharpe PT, Brandner S, Bliss TV, Henderson DJ, Nizetic D, Tybulewicz VL, Fisher EM (2005) An aneuploid mouse strain carrying human chromosome 21 with Down syndrome phenotypes. Science 309(5743):2033-2037

Odom GL, Gregorevic P, Chamberlain JS (2007) Viral-mediated gene therapy for the muscular dystrophies: successes, limitations and recent advances. Biochim Biophys Acta 1772(2): 243-262

Ohzeki J, Bergmann JH, Kouprina N, Noskov VN, Nakano M, Kimura H, Earnshaw WC, Larionov V, Masumoto H (2012) Breaking the HAC barrier: histone $\mathrm{H} 3 \mathrm{~K} 9$ acetyl/methyl balance regulates CENP-A assembly. EMBO J 31(10):2391-2402

Okada Y (1993) Sendai virus-induced cell fusion. Methods Enzymol 221:18-41

Oshimura M, Barrett JC (1997) Multiple pathways to cellular senescence: role of telomerase repressors. Eur J Cancer 33(5):710-715

Oshimura M, Kazuki Y, Iida Y, Uno N (2013) New vectors for gene delivery: human and mouse artificial chromosomes. eLS., John Wiley \& Sons, Ltd, Chichester

Otsuki A, Tahimic CG, Tomimatsu N, Katoh M, Chen DJ, Kurimasa A, Oshimura M (2005) Construction of a novel expression system on a human artificial chromosome. Biochem Biophys Res Commun 329(3):1018-1025

Qi DL, Ohhira T, Fujisaki C, Inoue T, Ohta T, Osaki M, Ohshiro E, Seko T, Aoki S, Oshimura M, Kugoh H (2011) Identification of PITX1 as a TERT suppressor gene located on human chromosome 5. Mol Cell Biol 31(8):1624-1636

Ramírez-Solis R, Liu P, Bradley A (1995) Chromosome engineering in mice. Nature 378(6558):720-724

Ren X, Katoh M, Hoshiya H, Kurimasa A, Inoue T, Ayabe F, Shibata K, Toguchida J, Oshimura M (2005) A novel human artificial chromosome vector provides effective cell lineagespecific transgene expression in human mesenchymal stem cells. Stem Cells 23(10):1608-1616

Rocchi L, Braz C, Cattani S, Ramalho A, Christan S, Edlinger M, Ascenzioni F, Laner A, Kraner S, Amaral M, Schindelhauer D (2010) Escherichia coli-cloned CFTR loci relevant for human artificial chromosome therapy. Hum Gene Ther 21(9):1077-1092
Sander JD, Joung JK (2014) CRISPR-Cas systems for editing, regulating and targeting genomes. Nat Biotechnol 32(4): 347-355

Seraj MJ, Samant RS, Verderame MF, Welch DR (2000) Functional evidence for a novel human breast carcinoma metastasis suppressor, BRMS1, encoded at chromosome 11q13. Cancer Res 60(11):2764-2769

Seyda A, Newbold RF, Hudson TJ, Verner A, MacKay N, Winter S, Feigenbaum A, Malaney S, Gonzalez-Halphen D, Cuthbert AP, Robinson BH (2001) A novel syndrome affecting multiple mitochondrial functions, located by microcell-mediated transfer to chromosome 2p14-2p13. Am J Hum Genet 68(2):386-396

Shen MH, Yang J, Loupart ML, Smith A, Brown W (1997) Human mini-chromosomes in mouse embryonal stem cells. Hum Mol Genet 6(8):1375-1382

Shinohara T, Tomizuka K, Miyabara S, Takehara S, Kazuki Y, Inoue J, Katoh M, Nakane H, Iino A, Ohguma A, Ikegami S, Inokuchi K, Ishida I, Reeves RH, Oshimura M (2001) Mice containing a human chromosome 21 model behavioral impairment and cardiac anomalies of Down's syndrome. Hum Mol Genet 10(11):1163-1175

Shitara S, Kakeda M, Nagata K, Hiratsuka M, Sano A, Osawa K, Okazaki A, Katoh M, Kazuki Y, Oshimura M, Tomizuka K (2008) Telomerase-mediated life-span extension of human primary fibroblasts by human artificial chromosome (HAC) vector. Biochem Biophys Res Commun 369(3):807-811

Stewart S, MacDonald N, Perkins E, DeJong G, Perez C, Lindenbaum M (2002) Retrofitting of a satellite repeat DNA-based murine artificial chromosome (ACes) to contain loxP recombination sites. Gene Ther 9(11):719-723

Suda T, Katoh M, Hiratsuka M, Takiguchi M, Kazuki Y, Inoue T, Oshimura M (2006) Heat-regulated production and secretion of insulin from a human artificial chromosome vector. Biochem Biophys Res Commun 340(4):1053-1061

Suzuki N, Itou T, Hasegawa Y, Okazaki T, Ikeno M (2010) Cell to cell transfer of the chromatin-packaged human beta-globin gene cluster. Nucleic Acids Res 38(5):e33

Suzuki N, Nishii K, Okazaki T, Ikeno M (2006) Human artificial chromosomes constructed using the bottom-up strategy are stably maintained in mitosis and efficiently transmissible to progeny mice. J Biol Chem 281(36):26615-26623

Suzuki T, Kazuki Y, Oshimura M, Hara T (2014) A novel system for simultaneous or sequential integration of multiple geneloading vectors into a defined site of a human artificial chromosome. PLoS One 9(10):e110404

Takahashi Y, Tsuji S, Kazuki Y, Noguchi M, Arifuku I, Umebayashi Y, Nakanishi T, Oshimura M, Sato K (2010) Development of evaluation system for bioactive substances using human artificial chromosome-mediated osteocalcin gene expression. J Biochem 148(1):29-34

Takiguchi, M., Kazuki, Y., Hiramatsu, K., Abe, S., Iida, Y., Takehara, S., Nishida, T., Ohbayashi, T., Wakayama, T. and Oshimura, M. (2012) A novel and stable mouse artificial chromosome vector. ACS Synth Biol

Tanaka H, Shimizu M, Horikawa I, Kugoh H, Yokota J, Barrett JC, Oshimura M (1998) Evidence for a putative telomerase repressor gene in the 3p14.2-p21.1 region. Genes Chromosomes Cancer 23(2):123-133

Tedesco FS, Cossu G (2012) Stem cell therapies for muscle disorders. Curr Opin Neurol 25(5):597-603 
Tedesco, F. S., Gerli, M. F., Perani, L., Benedetti, S., Ungaro, F., Cassano, M., Antonini, S., Tagliafico, E., Artusi, V., Longa, E., Tonlorenzi, R., Ragazzi, M., Calderazzi, G., Hoshiya, H., Cappellari, O., Mora, M., Schoser, B., Schneiderat, P., Oshimura, M., Bottinelli, R., Sampaolesi, M., Torrente, Y., Broccoli, V. and Cossu, G. (2012) Transplantation of genetically corrected human iPSC-derived progenitors in mice with limb-girdle muscular dystrophy. Sci Transl Med, 4(140), 140ra89.

Tedesco, F. S., Hoshiya, H., D’Antona, G., Gerli, M. F., Messina, G., Antonini, S., Tonlorenzi, R., Benedetti, S., Berghella, L., Torrente, Y., Kazuki, Y., Bottinelli, R., Oshimura, M. and Cossu, G. (2011) Stem cell-mediated transfer of a human artificial chromosome ameliorates muscular dystrophy. Sci Transl Med, 3(96), 96ra78.

Telenius H, Szeles A, Keresö J, Csonka E, Praznovszky T, Imreh S, Maxwell A, Perez CF, Drayer JI, Hadlaczky G (1999) Stability of a functional murine satellite DNA-based artificial chromosome across mammalian species. Chromosome Res 7(1):3-7

Tomizuka K, Shinohara T, Yoshida H, Uejima H, Ohguma A, Tanaka S, Sato K, Oshimura M, Ishida I (2000) Double transchromosomic mice: maintenance of two individual human chromosome fragments containing Ig heavy and kappa loci and expression of fully human antibodies. Proc Natl Acad Sci U S A 97(2):722-727

Tomizuka K, Yoshida H, Uejima H, Kugoh H, Sato K, Ohguma A, Hayasaka M, Hanaoka K, Oshimura M, Ishida I (1997) Functional expression and germline transmission of a human chromosome fragment in chimaeric mice. Nat Genet 16(2): 133-143

Tóth A, Fodor K, Praznovszky T, Tubak V, Udvardy A, Hadlaczky G, Katona RL (2014) Novel method to load multiple genes onto a mammalian artificial chromosome. PLoS One 9(1):e85565

Uno N, Kazuki Y, Oshimura M (2014) Toward gene and cell therapies employing human artificial chromosomes in conjunction with stem cells. Cloning \& Transgenesis 3(122)

Uno N, Uno K, Zatti S, Ueda K, Hiratsuka M, Katoh M, Oshimura M (2013) The transfer of human artificial chromosomes via cryopreserved microcells. Cytotechnology 65(5):803-809

Upender MB, Habermann JK, McShane LM, Korn EL, Barrett JC, Difilippantonio MJ, Ried T (2004) Chromosome transfer induced aneuploidy results in complex dysregulation of the cellular transcriptome in immortalized and cancer cells. Cancer Res 64(19):6941-6949

Urnov FD, Rebar EJ, Holmes MC, Zhang HS, Gregory PD (2010) Genome editing with engineered zinc finger nucleases. Nat Rev Genet 11(9):636-646

Vanderbyl S, MacDonald GN, Sidhu S, Gung L, Telenius A, Perez C, Perkins E (2004) Transfer and stable transgene expression of a mammalian artificial chromosome into bone marrowderived human mesenchymal stem cells. Stem Cells 22(3): 324-333

Vanderbyl S, MacDonald N, de Jong G (2001) A flow cytometry technique for measuring chromosome-mediated gene transfer. Cytometry 44(2):100-105

Vanderbyl SL, Sullenbarger B, White N, Perez CF, MacDonald GN, Stodola T, Bunnell BA, Ledebur HC, Lasky LC (2005) Transgene expression after stable transfer of a mammalian artificial chromosome into human hematopoietic cells. Exp Hematol 33(12):1470-1476

Voet T, Schoenmakers E, Carpentier S, Labaere C, Marynen P (2003) Controlled transgene dosage and PAC-mediated transgenesis in mice using a chromosomal vector. Genomics 82(6):596-605

Wakai M, Abe S, Kazuki Y, Oshimura M, Ishikawa F (2014) A human artificial chromosome recapitulates the metabolism of native telomeres in mammalian cells. PLoS One 9(5):e98825

Yakura Y, Ishihara C, Kurosaki H, Kazuki Y, Komatsu N, Okada Y, Doi T, Takeya H, Oshimura M (2013) An induced pluripotent stem cell-mediated and integrationfree factor VIII expression system. Biochem Biophys Res Commun 431(2):336-341

Yamada H, Kunisato A, Kawahara M, Tahimic CG, Ren X, Ueda H, Nagamune T, Katoh M, Inoue T, Nishikawa M, Oshimura M (2006) Exogenous gene expression and growth regulation of hematopoietic cells via a novel human artificial chromosome. J Hum Genet 51(2):147-150

Yamada H, Li YC, Nishikawa M, Oshimura M, Inoue T (2008) Introduction of a CD40L genomic fragment via a human artificial chromosome vector permits cell-type-specific gene expression and induces immunoglobulin secretion. J Hum Genet 53(5):447-453

Yamaguchi S, Kazuki Y, Nakayama Y, Nanba E, Oshimura M, Ohbayashi T (2011) A method for producing transgenic cells using a multi-integrase system on a human artificial chromosome vector. Plos One 6(2)

Yamaguchi S, Ren X, Katoh M, Miyata K, Fukushima H, Inoue $T$, Oshimura $M$ (2006) A new method of microcell-mediated transfer of human artificial chromosomes using a hemagglutinating virus of Japan envelope. Chromosome Science 9(2):65-73

Yang J, Shen MH (2006) Polyethylene glycol-mediated cell fusion. Methods Mol Biol 325:59-66

Zatti S, Martewicz S, Serena E, Uno N, Giobbe G, Kazuki Y, Oshimura M, Elvassore N (2014) complete restoration of multiple dystrophin isoforms in genetically corrected Duchenne musclar dystropy patient-derived cardiomyocytes. Molecular Therapy_-Methods \& Clinical Development 1(1):1-9 